\title{
Variations in $\mathrm{O}_{3}, \mathrm{CO}$, and $\mathrm{CH}_{4}$ over the Bay of Bengal during the summer monsoon season: shipborne measurements and model simulations
}

\author{
Imran A. Girach ${ }^{1,2}$, Narendra Ojha ${ }^{2}$, Prabha R. Nair ${ }^{1}$, Andrea Pozzer ${ }^{2}$, Yogesh K. Tiwari ${ }^{3}$, K. Ravi Kumar ${ }^{4,5}$, and \\ Jos Lelieveld ${ }^{2}$ \\ ${ }^{1}$ Space Physics Laboratory, Vikram Sarabhai Space Centre, Thiruvananthapuram 695022, India \\ ${ }^{2}$ Department of Atmospheric Chemistry, Max Planck Institute for Chemistry, Mainz 55128, Germany \\ ${ }^{3}$ Indian Institute of Tropical Meteorology, Pune 411 008, India \\ ${ }^{4}$ National Institute of Polar Research, Tachikawa, Japan \\ ${ }^{5}$ Department of Environmental Geochemical Cycle Research, JAMSTEC, Yokohama, Japan
}

Correspondence to: Imran A. Girach (imran.girach@gmail.com) and Narendra Ojha (narendra.ojha@mpic.de)

Received: 7 July 2016 - Published in Atmos. Chem. Phys. Discuss.: 13 July 2016

Revised: 17 November 2016 - Accepted: 8 December 2016 - Published: 5 January 2017

\begin{abstract}
We present shipborne measurements of surface ozone $\left(\mathrm{O}_{3}\right)$, carbon monoxide $(\mathrm{CO})$, and methane $\left(\mathrm{CH}_{4}\right)$ over the Bay of Bengal (BoB), the first time such measurements have been performed during the summer monsoon season, as a part of the Continental Tropical Convergence Zone (CTCZ) experiment during 2009. $\mathrm{O}_{3}, \mathrm{CO}$, and $\mathrm{CH}_{4}$ mixing ratios exhibited significant spatial and temporal variability in the ranges of $8-54 \mathrm{nmol} \mathrm{mol}^{-1}, 50-200 \mathrm{nmol} \mathrm{mol}^{-1}$, and $1.57-$ $2.15 \mu \mathrm{mol} \mathrm{mol}^{-1}$, with means of $29.7 \pm 6.8 \mathrm{nmol} \mathrm{mol}^{-1}$, $96 \pm 25 \mathrm{nmol} \mathrm{mol}^{-1}$, and $1.83 \pm 0.14 \mu \mathrm{mol} \mathrm{mol}^{-1}$, respectively. The average mixing ratios of trace gases over $\mathrm{BoB}$ in air masses from central/northern India $\left(\mathrm{O}_{3}: 30 \pm 7 \mathrm{nmol} \mathrm{mol}^{-1}\right.$; $\mathrm{CO}: 95 \pm 25 \mathrm{nmol} \mathrm{mol}^{-1} ; \mathrm{CH}_{4}$ : $1.86 \pm 0.12 \mu \mathrm{mol} \mathrm{mol}^{-1}$ ) were not statistically different from those in air masses from southern India $\left(\mathrm{O}_{3}\right.$ : $27 \pm 5 \mathrm{nmol} \mathrm{mol}^{-1} ; \quad \mathrm{CO}: \quad 101 \pm 27 \mathrm{nmol} \mathrm{mol}^{-1} ; \quad \mathrm{CH}_{4}$ : $\left.1.72 \pm 0.14 \mu \mathrm{mol} \mathrm{mol}^{-1}\right)$. Spatial variability is observed to be most significant for $\mathrm{CH}_{4}$ with higher mixing ratios in the air masses from central/northern India, where higher $\mathrm{CH}_{4}$ levels are seen in the SCIAMACHY (SCanning Imaging Absorption spectroMeter for Atmospheric CartograpHY) data. $\mathrm{O}_{3}$ mixing ratios over the $\mathrm{BoB}$ showed large reductions (by $\sim 20 \mathrm{nmol} \mathrm{mol}^{-1}$ ) during four rainfall events. Temporal changes in the meteorological parameters, in conjunction with $\mathrm{O}_{3}$ vertical profile, indicate that these low- $\mathrm{O}_{3}$ events are associated with downdrafts of free-tropospheric $\mathrm{O}_{3}$-poor air masses. While the observed variations of $\mathrm{O}_{3}$ and $\mathrm{CO}$
\end{abstract}

are successfully reproduced using the Weather Research and Forecasting model with Chemistry (WRF-Chem), this model overestimates mean concentrations by about 6 and $16 \%$ for $\mathrm{O}_{3}$ and $\mathrm{CO}$, respectively, generally overestimating $\mathrm{O}_{3}$ mixing ratios during the rainfall events. An analysis of modelled $\mathrm{O}_{3}$ along air mass trajectories show mean en route $\mathrm{O}_{3}$ production rate of about $4.6 \mathrm{nmol} \mathrm{mol}^{-1} \mathrm{day}^{-1}$ in the outflow towards the BoB. Analysis of the various tendencies from model simulations during an event on 10 August 2009 , reproduced by the model, shows horizontal advection rapidly transporting $\mathrm{O}_{3}$-rich air masses from near the coast across the BoB. This study fills a gap in the availability of trace gas measurements over the $\mathrm{BoB}$ and, when combined with data from previous campaigns, reveals large seasonal amplitude $\left(\sim 39\right.$ and $\sim 207 \mathrm{nmol} \mathrm{mol}^{-1}$ for $\mathrm{O}_{3}$ and $\mathrm{CO}$, respectively) over the northern $\mathrm{BoB}$.

\section{Introduction}

Tropospheric ozone $\left(\mathrm{O}_{3}\right)$ is the third most important greenhouse gas, contributing to global warming and climate change with a radiative forcing of $0.40 \pm 0.20 \mathrm{Wm}^{-2}$ (IPCC, 2013). $\mathrm{O}_{3}$ is also a pivotal trace gas in tropospheric chemistry, as it is a major source of hydroxyl radical $(\mathrm{OH})$, which removes most of the organic compounds and pollutants from 
the atmosphere and controls the oxidation capacity of the troposphere (e.g. Brasseur et al., 1999; Finlayson-Pitts and Pitts, 2003; Seinfeld and Pandis, 2006). Further, enhanced concentrations of surface $\mathrm{O}_{3}$ have detrimental effects on human health and vegetation (Heagle, 1989; Seinfeld and Pandis, 2006). Approximately $80 \%$ of tropospheric $\mathrm{O}_{3}$ is produced by in situ photochemical reactions in the presence of nitrogen oxides $\left(\mathrm{NO}_{x}=\mathrm{NO}+\mathrm{NO}_{2}\right)$ involving the precursor gases of methane, non-methane hydrocarbons (NMHCs), and CO (Fishman et al., 1979; Crutzen et al., 1999; Seinfeld and Pandis, 2006). The remaining $20 \%$ of tropospheric $\mathrm{O}_{3}$ is attributed to intrusions of stratospheric air during frontal activities or to tropopause folding events (Lelieveld and Dentener, 2000; Sprenger et al., 2007). Depending upon meteorological conditions and the availability of the aforementioned precursors, a net production or destruction of $\mathrm{O}_{3}$ prevails. The average lifetime of $\mathrm{O}_{3}$ is about 1 week in the lower troposphere, which leads to large variability in its spatial and temporal distributions, as compared to the long-lived greenhouse gases. The budget of tropospheric $\mathrm{O}_{3}$ and its implications for human health, crop yields, and climate are, however, not yet well quantified, especially over regions in Asia. This is mainly due to a lack of in situ measurements (e.g. Cooper et al., 2014; Monks et al., 2015).

Carbon monoxide (CO) is an indirect greenhouse gas which also has adverse effects on the health of humans and animals (WHO, 1999). Although it does not have a direct greenhouse effect like methane and carbon dioxide, its role in atmospheric chemistry is estimated to cause an indirect radiative forcing of $0.23(0.18-0.29) \mathrm{Wm}^{-2}$ (IPCC, 2013). The major sources of $\mathrm{CO}$ are fossil fuel combustion, biomass burning, and oxidation of hydrocarbons such as $\mathrm{CH}_{4}$ and isoprene (e.g. Jacob, 1999; Bergamaschi et al., 2000; Seinfeld and Pandis, 2006).

Methane $\left(\mathrm{CH}_{4}\right)$ is one of the major greenhouse gases, with a direct radiative forcing of $0.48 \pm 0.05 \mathrm{Wm}^{-2}$ (IPCC, 2013). This gas plays a major role in the climate and in atmospheric chemistry. $\mathrm{CH}_{4}$ is emitted from variety of natural and anthropogenic sources (Jacob, 1999) and is removed primarily through its reaction with OH radicals (Fung et al., 1991; Seinfeld and Pandis, 2006).

The marine regions adjoining South Asia have been observed to have elevated levels of surface $\mathrm{O}_{3}$ due to the outflow of continental pollution (Lawrence and Lelieveld, 2010) and minimal chemical loss by titration (e.g. Lal and Lawrence, 2001; Ojha et al., 2012). Suggested sources for this elevated $\mathrm{O}_{3}$ and other trace gases observed over the marine regions surrounding India are anthropogenic, biomass burning, and biogenic emissions over continental India (Naja et al., 2004; Lawrence and Lelieveld, 2010; Nair et al., 2011; David et al., 2011). The air masses influenced by continental emissions undergo chemical transformation, including $\mathrm{O}_{3}$ production, during their transport to the cleaner marine regions. In situ measurements over the marine regions are required to understand the effects of direct outflow, en route chemical transformation, and the chemistry in the transported air masses (Lawrence and Lelieveld, 2010, and references therein).

The experiments that have been conducted to date over the marine environment adjacent to the Indian region have revealed considerable spatial heterogeneity in the distribution of trace gases and aerosols, influences from source regions such as the Indo-Gangetic Plain (IGP), and radiative impacts (Nair et al., 2010, 2011; David et al., 2011; Mallik et al., 2013; Moorthy et al., 2009). Observations made during the Indian Ocean Experiment (INDOEX; Lal and Lawrence, 2001) and model simulations (Ojha et al., 2012) both found the $\mathrm{O}_{3}$ mixing ratios over these remote marine regions to be even higher than those over the upwind continental regions due to complex $\mathrm{O}_{3}$ chemistry. Lawrence and Lelieveld (2010) provided a detailed review of the outflow of trace gases and aerosols from South Asia to the surrounding marine regions. Transport of air masses between the Indian subcontinent and the adjacent marine regions has strong seasonal dependence associated with the monsoonal circulation (e.g. Kumar et al., 2015a).

The marine environment of the Bay of Bengal (BoB), the largest bay in the world, is surrounded by landmasses on three sides, making it highly suitable to observe enhanced concentrations of trace species. Further, seasonal changes in synoptic winds make this a unique region to study variations in trace species due to transport and en route photochemistry. Considering the aforementioned special characteristics of the BoB, as well as the considerable heterogeneity of trace gas and aerosol distribution, in situ measurements covering large areas are essential for investigating the distribution of pollutants and the controlling processes. Extensive in situ measurements of various trace gases over the $\mathrm{BoB}$ have been conducted in the following field campaigns: INDOEX during the winter months of 1998 and 1999 (Lelieveld et al., 2001; Mühle et al., 2002); the Integrated Campaign for Aerosols, gases, and Radiation Budget (ICARB) during the March-May (pre-monsoon season) of 2006 (Nair et al., 2011; Srivastava et al., 2011, 2012); the winter-ICARB (WICARB) during December-January 2009 (Girach and Nair, 2010, 2014; David et al., 2011); the Bay of Bengal Experiment (BOBEX)-I during February-March 2001 (Lal et al., 2006); the Bay of Bengal Process Studies (BOBPS) during September-October 2002 (Sahu et al., 2006); BOBEX-II during February 2003 (Lal et al., 2007); and the other campaign conducted during October-November 2010 (Mallik et al., 2013).

Although earlier studies have covered the spatio-temporal distribution of trace gases during most seasons over the BoB, there is still a lack of observations over the $\mathrm{BoB}$ during the summer monsoon season (June-August). The Asian summer monsoon circulation provides a pathway for pollution transport into the stratosphere (Randel et al., 2010), and observations taken during monsoon season capture a time of high water-vapour loading over the BoB. Deep convection during 


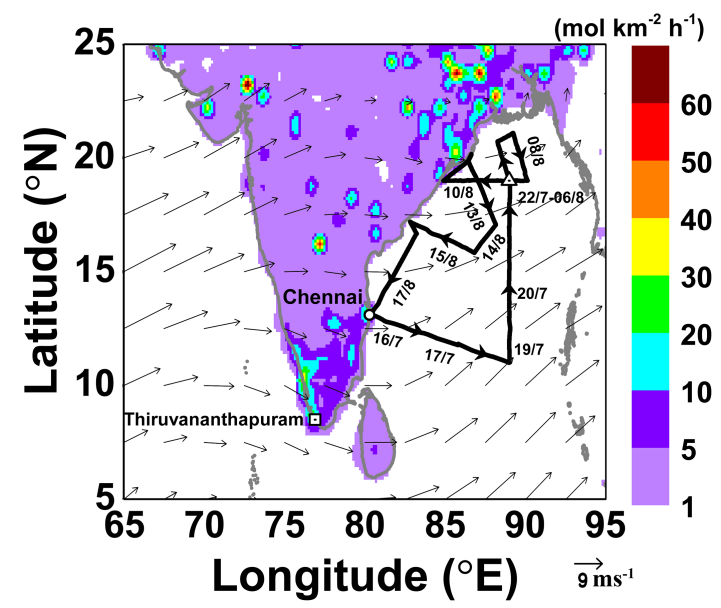

Figure 1. Cruise track (continuous black line) of the Research Vessel Sagar Kanya along with synoptic winds at $925 \mathrm{hPa}$ (black thin arrows) and $\mathrm{NO}_{x}$ emissions in background colour map. The dates corresponding to approximate ship positions are marked along the track. The start and end position of the cruise, stationary position of the ship, and Thiruvananthapuram are shown by the circle, triangle and square, respectively.

the summer monsoon can uplift boundary layer pollution to higher altitudes; the pollution is then distributed over a larger region, thereby influencing air quality and climate over much larger regions (Lawrence and Lelieveld, 2010), extending as far as, for example, over the Mediterranean (e.g. Lelieveld et al., 2002; Scheeren et al., 2003). Such in situ measurements are also essential given the fact that satellite remote sensing of boundary layer $\mathrm{O}_{3}$ has relatively higher uncertainty. The uncertainties in satellite retrievals of trace species are particularly high during the summer monsoon season, as the view of satellite instruments is frequently obscured by thick clouds.

In the present paper, the ship-based measurements of surface $\mathrm{O}_{3}, \mathrm{CO}$, and $\mathrm{CH}_{4}$ over the $\mathrm{BoB}$ are presented for the summer monsoon season of 2009. These observations were carried out as a part of the Continental Tropical Convergence Zone (CTCZ) experiment (http://www.incois.gov.in/portal/ datainfo/pdctcz.jsp) under the Indian Climate Research Programme (ICRP) of the Government of India. In this study, the spatial and temporal variations of $\mathrm{O}_{3}$ over the $\mathrm{BoB}$ and the effects of transport are analysed. These observations are compared with simulations from a regional model, Weather Research and Forecasting coupled with Chemistry (WRFChem). The sharp reductions observed in $\mathrm{O}_{3}$ during rainfall events are investigated in greater detail.

\section{The cruise track and background conditions}

Figure 1 shows the cruise track of the Oceanic Research Vessel (ORV) Sagar Kanya during the CTCZ campaign (cruise number SK 261). The arrows marked on the track show the direction of the ship, which sailed from Chennai $\left(80.3^{\circ} \mathrm{E}\right.$, $13.1^{\circ} \mathrm{N}$; marked by a circle) on 16 July 2009 . The cruise offered greater coverage in the northern BoB than the southern or central BoB areas. To take time series measurements, the ship was kept stationary for 15 days (22 July to 6 August 2009 ) at $89^{\circ} \mathrm{E}, 19^{\circ} \mathrm{N}$ as marked by a triangle in the figure. After several tracks, covering latitude sector 11.0 to $21.1^{\circ} \mathrm{N}$ and longitude sector 80.3 to $90.1^{\circ} \mathrm{E}$, the cruise ended on 17 August 2009 at Chennai, for a total of 32 days of voyage. The average wind pattern at $925 \mathrm{hPa}$ (NCEP/NCAR reanalysis; http://www.esrl.noaa.gov/psd) during the cruise period is shown in Fig. 1. The prevailing westerly and southwesterly winds transport $\mathrm{O}_{3}$ and its precursors from the Indian landmass to the $\mathrm{BoB}$ during the study period. The spatial distribution of emissions of $\mathrm{NO}_{x}$, an $\mathrm{O}_{3}$ precursor gas, is also shown as colour map in Fig. $1 . \mathrm{NO}_{x}$ emissions are obtained from the Intercontinental Chemical Transport Experiment Phase B (INTEX-B) inventory (Zhang et al., 2009), which is representative of the year 2006. $\mathrm{NO}_{x}$ emissions are relatively higher over parts of eastern and southern India as compared to central India. The square tagged as Thiruvananthapuram shows the location corresponding to the measurements shown in Fig. 9.

\section{Experimental details and data}

Surface $\mathrm{O}_{3}$ measurements were carried out using an online ultraviolet (UV) photometric ozone analyzer (model O3 42), manufactured by Environnement S.A, France. The analyser utilises the absorption of UV radiation by $\mathrm{O}_{3}$ molecules at $253.7 \mathrm{~nm}$ and derives $\mathrm{O}_{3}$ mixing ratios using the BeerLambert law. This UV absorption-based analyser has an uncertainty of about $5 \%$ (Tanimoto et al., 2007), corresponding to $\sim 1.5 \mathrm{nmol} \mathrm{mol}^{-1}$ for the observed range of $\mathrm{O}_{3}$. Zero noise of the instrument is $0.5 \mathrm{nmol} \mathrm{mol}^{-1}$. The instrument has a lower detection limit of $1 \mathrm{nmol} \mathrm{mol}^{-1}$ and a linearity of $\pm 1 \%$. An individual measurement is performed at a minimum response time of $10 \mathrm{~s}$. The analyzer was operated on auto-response mode, whereby responses could be 10-90 s depending upon changes in $\mathrm{O}_{3}$ mixing ratios. However, data were recorded continuously at $5 \mathrm{~min}$ intervals.

$\mathrm{CO}$ measurements were made using an online $\mathrm{CO}$ analyzer (model CO12 Module) manufactured by Environnement S.A, France. This instrument works on the principle of nondispersive infrared (NDIR) absorption by $\mathrm{CO}$ molecules at the wavelength of $4.67 \mu \mathrm{m}$. The instrument has a lower detection limit of $50 \mathrm{nmol} \mathrm{mol}^{-1}$, a linearity of $1 \%$, and a response time of $40 \mathrm{~s}$. The overall uncertainty in hourly $\mathrm{CO}$ measurements is estimated to be $\sim 10 \%$ at a $\mathrm{CO}$ value of $150 \mathrm{nmol} \mathrm{mol}^{-1}$ (Sawa et al., 2007; Tanimoto et al., 2007).

Air was drawn from a height of approximately $15 \mathrm{~m}$ above the sea surface through a Teflon tube. Before and after the cruise, both analyzers were calibrated, with calibration factors not found to be significantly changed. The calibrations of both analysers were carried out using appropriate calibration 


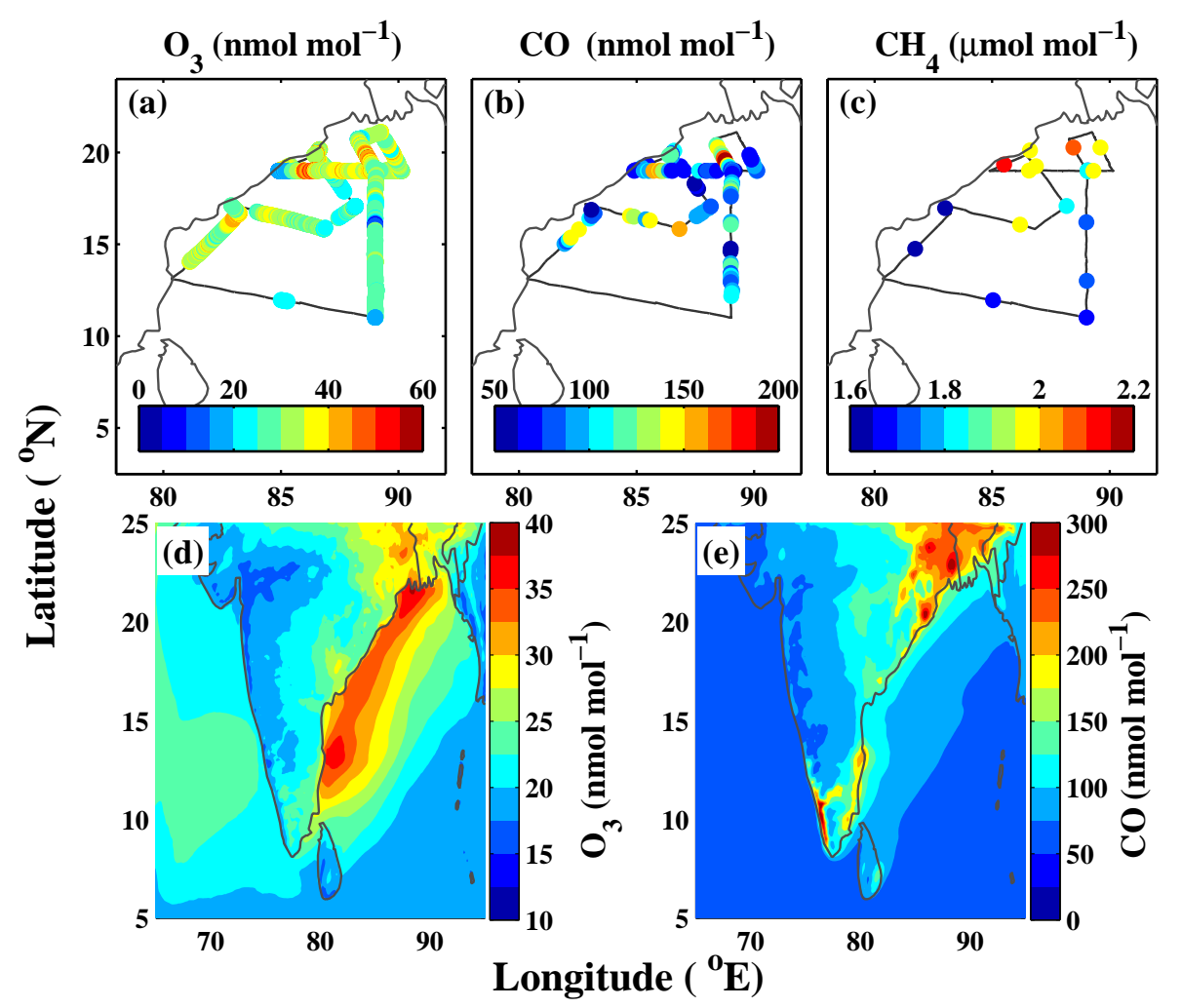

Figure 2. Spatial variation of surface $\mathrm{O}_{3}(\mathbf{a}), \mathrm{CO}(\mathbf{b})$, and $\mathrm{CH}_{4}$ (c) mixing ratios along the cruise track during the CTCZ campaign. WRFChem simulated spatial distribution of surface $\mathrm{O}_{3}$ (d) and $\mathrm{CO}(\mathbf{e})$ averaged during 16 July-17 August 2009.

standards traceable to NIST and a multi-channel calibrator, following the procedure mentioned in the manuals of analysers. While the $\mathrm{O}_{3}$ analyser was calibrated for mixing ratios of $30 \mathrm{nmol} \mathrm{mol}^{-1}$, the $\mathrm{CO}$ analyser was calibrated for mixing ratios of $1.1 \mu \mathrm{mol} \mathrm{mol}^{-1}$. Meteorological parameters such as pressure, temperature, and relative humidity were measured continuously on board the ship. Trace gas measurements affected by the ship exhaust were identified and discarded using on-board wind direction and $\mathrm{NO}_{x}$ measurements.

In addition, a total of 29 air samples were collected in $1 \mathrm{~L}$ glass flasks during the cruise and were analysed for $\mathrm{CH}_{4}$ using a gas chromatograph (GC) coupled with a flame ionisation detector (FID), as described in Tiwari and Ravi Kumar (2011). These $\mathrm{CH}_{4}$ measurements are traceable to the WMO standard scale. $\mathrm{CH}_{4}$ standards were obtained from the WMO Central Calibration Laboratory (CCL) at the National Oceanic and Atmospheric Administration (NOAA)/Earth System Research Laboratory (ESRL)/Global Monitoring Division (GMD), located in Boulder, Colorado, USA. The precision for $\mathrm{CH}_{4}$ measurements was approximately $\pm 0.1 \mu \mathrm{mol} \mathrm{mol}^{-1}$. A detailed description of the analytical procedure for $\mathrm{CH}_{4}$ measurement and calibration of GC is given in Ravikumar et al. (2014).

To further study the observed low- $\mathrm{O}_{3}$ events over $\mathrm{BoB}$, measurements made at Thumba, Thiruvananthapuram, are used as a case study. Using the same $\mathrm{O}_{3}$ analyzer as the one used for surface $\mathrm{O}_{3}$ measurements over $\mathrm{BoB}$, continuous measurements of surface $\mathrm{O}_{3}$ were taken at Thumba, Thiruvananthapuram (David and Nair, 2011; Girach et al., 2012), in July 2011. Along with various meteorological parameters, rainfall measurements were also taken at Thumba at $5 \mathrm{~min}$ of integration time using an automatic weather station manufactured by Dynalab Weathertech Pvt. Ltd, India. The site, Thumba, is situated just $\sim 500 \mathrm{~m}$ away from the west coast, with sandy terrain, and is a less populated area in the city of Thiruvananthapuram $\left(8.5^{\circ} \mathrm{N}, 76.9^{\circ} \mathrm{E}\right)$ at southern tip of India. For more details about the Thumba site and measurements please see, for example, Nair et al. (2002) and David and Nair (2011).

A vertical profile of $\mathrm{O}_{3}$ was measured on 28 July 2011 at Thumba using an electrochemical concentration cell ozonesonde (EN-SCI 2ZV7 ECC; Komhyr, 1969; Komhyr et al., 1995). The accuracy of such ozonesondes is reported to be about $\pm 5-10 \%$ up to $\sim 30 \mathrm{~km}$ (Smit et al., 2007). More details of this measurement technique can be found in Ojha et al. (2014).

The accumulated rainfall for every $3 \mathrm{~h}$ interval from the Tropical Rainfall Measuring Mission (TRMM; with a horizontal grid size of $0.25^{\circ} \times 0.25^{\circ}$ ) is also utilised in this study to complement the on-board rainfall measurements. 
The 3B42 algorithm is used to calculate precipitation and root-mean-square precipitation-error estimates; these two estimates were then used to compute hourly and daily rainfall estimates (Huffman et al., 1995).

The gridded $\left(2^{\circ} \times 2^{\circ}\right)$ monthly column-averaged $\mathrm{CH}_{4}$ (level 3, version 6) retrievals from SCIAMACHY (SCanning Imaging Absorption spectroMeter for Atmospheric CartograpHY) instrument on board the Envisat satellite were used to infer concentrations over Indian land regions. The IMAP-DOAS (iterative maximum a posteriori differential optical absorption spectroscopy) algorithm was used, which retrieves $\mathrm{CH}_{4}$ utilising the spectra (i.e. $1000-1750 \mathrm{~nm}$ ) from the near infrared channel no. 6 (Frankenberg et al., 2005).

\section{Model simulations}

WRF-Chem (Grell et al., 2005) version 3.5.1 was used to simulate meteorological and chemical fields during the campaign period. The model domain (Fig. 2d-e) is defined on the Mercator projection, centred at $80^{\circ} \mathrm{E}, 15.5^{\circ} \mathrm{N}$, at a spatial resolution of $15 \mathrm{~km} \times 15 \mathrm{~km}$. The model has 51 vertical levels from surface to $10 \mathrm{hPa}$. The simulations were conducted for the period of 29 June to 31 August 2009, covering the complete measurement period. The meteorological inputs have been adopted from ERA-Interim reanalyses by the ECMWF. Horizontal winds, temperature, and water vapour are nudged above the planetary boundary layer using a nudging coefficient of $0.0003 \mathrm{~s}^{-1}$ (Kumar et al., 2015b), employing the four-dimensional data assimilation (FDDA) technique. Anthropogenic emissions of $\mathrm{CO}, \mathrm{NO}_{x}, \mathrm{SO}_{2}$, and NMVOCs are provided by a regional emission inventory that was developed to support INTEX-B (Zhang et al., 2009; Kumar et al., 2012b; Ojha et al., 2016). This inventory is representative of the year 2006. Aerosol emissions are provided by the Hemispheric Transport of Air Pollution (HTAP v2) inventory (Janssens-Maenhout et al., 2015). Biomass burning emissions from NCAR Fire Inventory (FINN; Wiedinmyer et al., 2011) and biogenic emissions calculated online using MEGAN (Guenther et al., 2006) were used in the simulations.

Gas-phase chemistry in the model is represented by the second-generation Regional Acid Deposition Model (RADM2; Stockwell et al., 1990), and the aerosol module is based on MADE SORGAM (Binkowski and Shankar, 1995; Ackermann et al., 1998; Schell et al., 2001). Initial and boundary conditions for chemical fields are provided by the MOZART-4/GEOS5 data. The options used to parameterise different atmospheric processes are given in Table 1. For more information about meteorological nudging, chemical mechanisms, emissions, boundary conditions, and evaluation of WRF-Chem against in situ measurements and satellite data over the Indian region, please see, for example, $\mathrm{Ku}-$ mar et al. (2012a, b, 2015a, b), Ansari et al. (2016), and Ojha et al. (2016). Model-simulated mean spatial distributions of

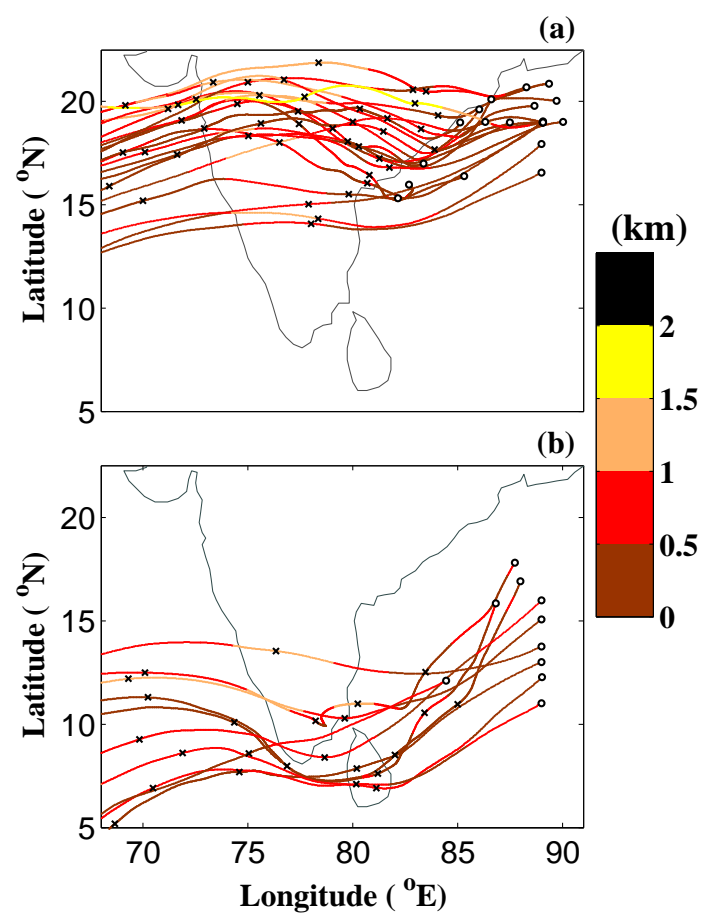

Figure 3. Five-day air mass back trajectories during the study period ending at the measurement locations (small black circles) grouped for corresponding air masses from (a) central/northern India and (b) southern India. The cross symbols along the trajectories represent each back-day. The colour scale shows the height (in $\mathrm{km}$ ) of the trajectories.

$\mathrm{O}_{3}$ and $\mathrm{CO}$ over the model domain during the study period are shown in Fig. 2d-e.

\section{Results and discussion}

\subsection{Variations in $\mathrm{O}_{3}, \mathrm{CO}$, and $\mathrm{CH}_{4}$ over the $\mathrm{BoB}$}

Figure $2 \mathrm{a}-\mathrm{c}$ show the observed variations in $\mathrm{O}_{3}, \mathrm{CO}$, and $\mathrm{CH}_{4}$ along the ship track during 16 July to 17 August 2009. The mixing ratios of trace gases show large spatio-temporal variations over the $\mathrm{BoB}$. Levels of $\mathrm{O}_{3}$ and $\mathrm{CO}$ varied in the ranges of 8-54 (average of $29.7 \pm 6.8 \mathrm{nmol} \mathrm{mol}^{-1}$ ) and 50 $200 \mathrm{nmol} \mathrm{mol}^{-1}$ (average of $96 \pm 25 \mathrm{nmol} \mathrm{mol}^{-1}$ ), respectively. As $\mathrm{CO}$ mixing ratios below the detection limit of the instrument are discarded from the analysis, the reported minimum and average values of $\mathrm{CO}$ mixing ratios are therefore slightly higher than their actual values. $\mathrm{CH}_{4}$ mixing ratios are observed to range from 1.57 to $2.15 \mu \mathrm{mol} \mathrm{mol}^{-1}$, with an average of $1.83 \pm 0.14 \mathrm{nmol} \mathrm{mol}^{-1}$. Average $\mathrm{CH}_{4}$ mixing ratios showed a significant difference of $\sim 0.14 \mu \mathrm{mol} \mathrm{mol}^{-1}$ between northern $\left(81-91^{\circ} \mathrm{E}, 16-21.5^{\circ} \mathrm{N}\right)$ and central $(80$ $\left.91^{\circ} \mathrm{E}, 11-16^{\circ} \mathrm{N}\right) \mathrm{BoB}$ during the study period. In addition to sailing across the $\mathrm{BoB}$, the ship was also kept stationary for 15 days, from 22 July to 6 August 2009 
Table 1. The WRF-Chem options used for parameterisation of atmospheric processes.

\begin{tabular}{lll}
\hline Atmospheric process & Scheme used & Features of the scheme \\
\hline Cloud microphysics & $\begin{array}{l}\text { Lin et al. scheme } \\
\text { (Lin et al., 1983) }\end{array}$ & $\begin{array}{l}\text { Sophisticated parameterisation including ice, snow, and } \\
\text { graupel processes; suitable for high-resolution simulations. }\end{array}$ \\
\hline Longwave radiation & $\begin{array}{l}\text { Rapid Radiative Transfer } \\
\text { Model (RRTM; Mlawer et al., 1997) }\end{array}$ & $\begin{array}{l}\text { Accurate scheme utilises look-up tables for efficiency and } \\
\text { accounts for multiple bands and microphysical properties. }\end{array}$ \\
\hline Shortwave radiation & $\begin{array}{l}\text { Goddard shortwave scheme } \\
\text { (Chou and Suarez, 1994) }\end{array}$ & $\begin{array}{l}\text { Two-stream multi-band scheme using O } 3 \\
\text { from climatology and includes cloud effects. }\end{array}$ \\
\hline Surface layer & $\begin{array}{l}\text { Monin-Obukhov scheme } \\
\text { (Janjic, 1996) }\end{array}$ & $\begin{array}{l}\text { Based on Monin-Obukhov with Zilitinkevich thermal roughness } \\
\text { length and standard similarity functions from look-up tables. }\end{array}$ \\
\hline Land surface option & $\begin{array}{l}\text { Noah land surface model } \\
\text { (Chen and Dudhia, 2001) }\end{array}$ & $\begin{array}{l}\text { Unified NCEP/NCAR/AFWA scheme with soil } \\
\text { temperature and moisture in four layers, fractional } \\
\text { snow cover and frozen soil physics. This includes the } \\
\text { modifications for better representation of processes } \\
\text { over ice sheets and snow covered areas. }\end{array}$ \\
\hline Urban surface physics & Urban canopy model & $\begin{array}{l}\text { Three-category urban canopy model with surface } \\
\text { effects for roofs, walls and streets. }\end{array}$ \\
\hline Planetary boundary layer & $\begin{array}{l}\text { Mellor-Yamada-Janjic } \\
\text { scheme (Janjic, 2002) }\end{array}$ & $\begin{array}{l}\text { One-dimensional prognostic turbulent kinetic } \\
\text { energy scheme; local vertical mixing is included. }\end{array}$ \\
\hline Cumulus parameterisation & $\begin{array}{l}\text { Grell 3D ensemble scheme } \\
\text { (Grell, 1993; Grell and Devenyi, 2002) }\end{array}$ & $\begin{array}{l}\text { Improved version of the GD scheme suitable } \\
\text { for coarse as well as high-resolution simulations. }\end{array}$ \\
\hline
\end{tabular}

at $89^{\circ} \mathrm{E}, 19^{\circ} \mathrm{N}$. During this time period, surface $\mathrm{O}_{3}$, $\mathrm{CO}$, and $\mathrm{CH}_{4}$ mixing ratios are observed to fall into the range of 9-46 nmol mol${ }^{-1}, 58-144 \mathrm{nmol} \mathrm{mol}^{-1}$, and 1.71$1.89 \mu \mathrm{mol} \mathrm{mol}^{-1}$, respectively, with temporally averaged mixing ratios of $28 \pm 7 \mathrm{nmol} \mathrm{mol}^{-1}, 91 \pm 19 \mathrm{nmol} \mathrm{mol}^{-1}$, and $1.81 \pm 0.06 \mu \mathrm{mol} \mathrm{mol}^{-1}$, respectively.

The HYbrid Single-Particle Lagrangian Integrated Trajectory (HYSPLIT) model was used to simulate 5-day backward air mass trajectories arriving at $500 \mathrm{~m}$ (a height that falls within the marine atmospheric boundary layer) above the measurement locations (Draxler and Rolph, 2003; Rolph, 2003; http://www.arl.noaa.gov/ready.html), as shown in the Fig. 3. Trajectories are colour-coded to show the altitude variations of the air parcels along their path. The influences of two different air masses are observed over the BoB during the CTCZ experiment. Over the central BoB, the backward air trajectories cross southern India (i.e. $<13^{\circ} \mathrm{N}$ ), where a belt of elevated anthropogenic emissions $\left(5-20 \mathrm{~mol} \mathrm{~km}^{-2} \mathrm{~h}^{-1}\right.$ of $\mathrm{NO}_{x}$; see Fig. 1) is located. In contrast, most of the air trajectories over northern BoB come across the central Indian region, where anthropogenic emissions are relatively lower. For example, with the exception of a few hotspots, $\mathrm{NO}_{x}$ emissions north of $13^{\circ} \mathrm{N}$ are in the range of $1-10 \mathrm{~mol} \mathrm{~km}^{-2} \mathrm{~h}^{-1}$ (Fig. 1). The $\mathrm{O}_{3}$ and $\mathrm{CO}$ mixing ratios over $\mathrm{BoB}$ in air masses from central/northern India (Fig. 3a) are slightly higher or comparable $\left(\mathrm{O}_{3}: 30 \pm 7\right.$; $\left.\mathrm{CO}: 95 \pm 25 \mathrm{nmol} \mathrm{mol}{ }^{-1}\right)$ to those $\left(\mathrm{O}_{3}: 27 \pm 5\right.$; CO: $\left.101 \pm 27 \mathrm{nmol} \mathrm{mol}^{-1}\right)$ in air masses from southern India (Fig. 3b).
The observed spatio-temporal variations of trace gases are investigated by calculating the fractional residence time of air masses over land, using HYSPLIT simulated 5-day backward air trajectories. Figure $4 \mathrm{a}-\mathrm{c}$ show the temporal variations of $\mathrm{O}_{3}, \mathrm{CO}$, and $\mathrm{CH}_{4}$ during the $\mathrm{CTCZ}$ experiment along the cruise track. The percentage of time of air masses over continental India is also shown (Fig. 4d), as estimated by the ratio of residence time over land to the total trajectory time of 5 days. The hours of residence have only been included in the analysis if the altitude along trajectory is less than $1.5 \mathrm{~km}$, as the surface emissions might not been directly influence the air masses aloft. Red vertical bars depict the sharp reductions in $\mathrm{O}_{3}$ mixing ratios associated with rainfall events (see Sect. 5.3). $\mathrm{O}_{3}, \mathrm{CO}$, and $\mathrm{CH}_{4}$ show correlated variability with the estimated residence times over the Indian subcontinent with slightly higher correlation in the case of primary species $\left(R^{2}=0.16\right.$ in case of $\mathrm{CO}$ and $\left.\mathrm{CH}_{4}\right)$, as compared to $\mathrm{O}_{3}\left(R^{2}=0.09\right)$. Similar variations in mixing ratios of these trace gases and residence time over continental India indicate the influences of transport from the Indian subcontinent on the observed spatio-temporal variations over the BoB during the summer monsoon season. The occasions on which such a one-to-one correspondence are not observed can be attributed to varying source strengths, vertical mixing or dilution, and en route photochemistry.

Generally, during the summer monsoon season, relatively cleaner marine air masses from the Arabian Sea are transported to the Indian region. These air masses are then exposed to regional emissions and subjected to photochemistry 

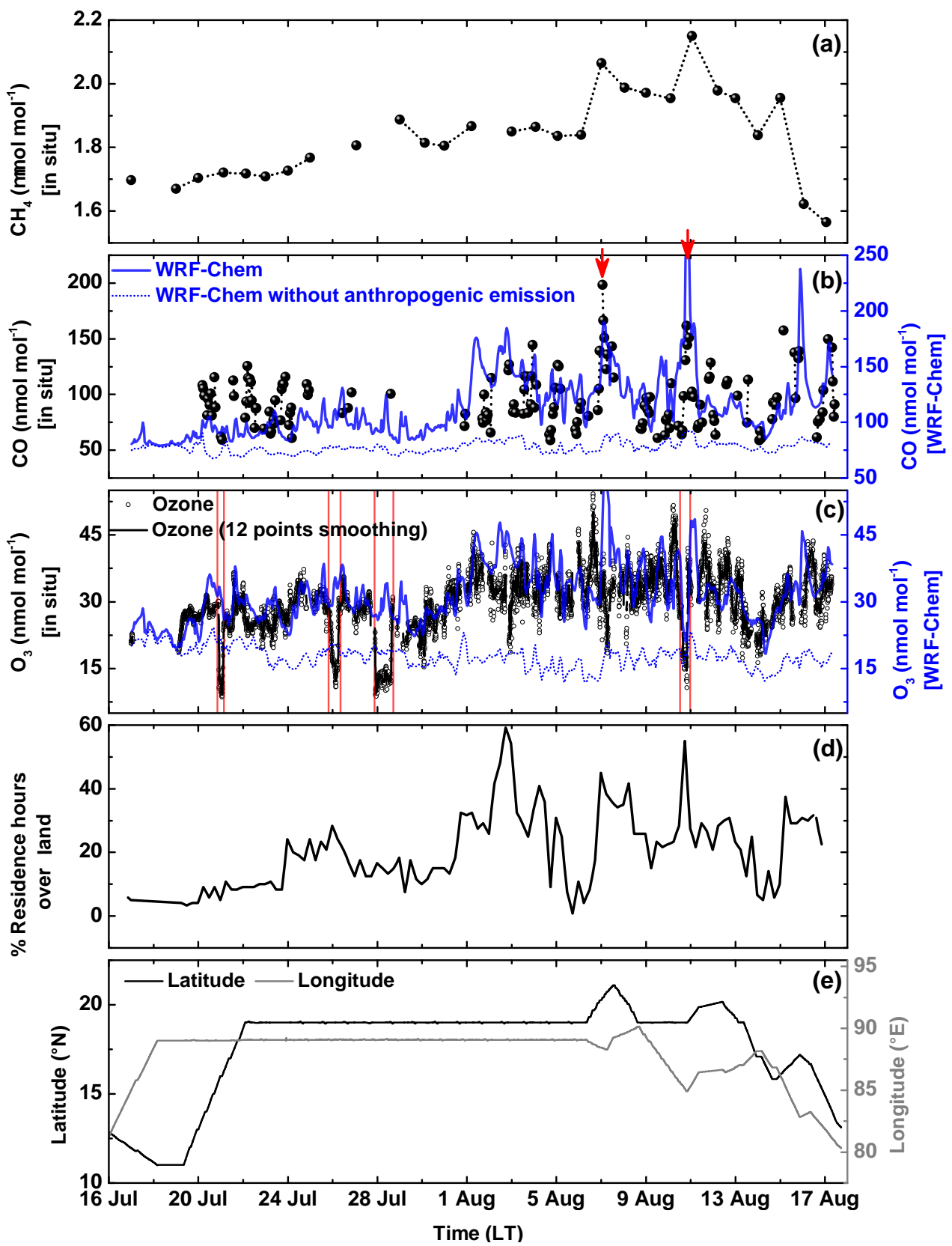

Figure 4. Variations in observed $\mathrm{CH}_{4}(\mathbf{a}), \mathrm{CO}(\mathbf{b}), \mathrm{O}_{3}(\mathbf{c})$, and percentage residence time over land (d) along with WRF-Chem simulated $\mathrm{O}_{3}$ and $\mathrm{CO}$ (blue line) during the campaign. Events of sharp decrease in $\mathrm{O}_{3}$ during rainfall are marked by vertical red lines (Fig. 8). (e) Variations in measurement locations.

depending upon the availability of solar insolation under the cloudy conditions of monsoon. The air masses in which precursors have accumulated, and to some extent photochemically processed, outflows into the $\mathrm{BoB}$. As a result, the air masses outflowing at the eastern coast of India could have higher $\mathrm{O}_{3}$ mixing ratios than the background air coming from the Arabian Sea into the western coast of India. The difference between these two values is representative of the $\mathrm{O}_{3}$ build-up that can be attributed to regional pollution; this dif- ference would also reflect the extent of photochemical processing that would have taken place.

As the observational site Thumba, Thiruvananthapuram, is situated just at the Arabian Sea coast, the monsoon-time observations here could be approximated to represent the background $\mathrm{O}_{3}$ mixing ratios entering from the Arabian Sea. In August 2009, using only daytime monthly average $\mathrm{O}_{3}$, the $\mathrm{O}_{3}$ at Thumba during the monsoon season was observed to be $23 \pm 7 \mathrm{nmol} \mathrm{mol}^{-1}$. Since the objective of in- 
Table 2. A comparison of averaged surface $\mathrm{O}_{3}$ mixing ratios measured at various sites during summer monsoon period.

\begin{tabular}{|c|c|c|c|c|c|}
\hline $\begin{array}{l}\text { Observation } \\
\text { site }\end{array}$ & $\begin{array}{r}\text { Longitude } \\
\left({ }^{\circ} \mathrm{E}\right)\end{array}$ & $\begin{array}{r}\text { Latitude } \\
\left({ }^{\circ} \mathrm{N}\right)\end{array}$ & Observation period & $\begin{array}{r}\text { Surface } \\
\text { daytime } \mathrm{O}_{3} \\
\text { (mean } \pm \text { standard } \\
\text { deviation) }\end{array}$ & Reference \\
\hline \multicolumn{6}{|l|}{ Arabian Sea } \\
\hline Arabian Sea & $69-76$ & $9-19$ & July-August 2002 & 9 & Ali et al. (2009) \\
\hline \multicolumn{6}{|l|}{ Western coast of India } \\
\hline $\begin{array}{l}\text { Thiruvananthapuram } \\
\text { Thiruvananthapuram } \\
\text { Kannur } \\
\text { MtAbu (1.6 km a.m.s.1.) } \\
\text { Ahmedabad }\end{array}$ & $\begin{array}{l}76.9 \\
76.9 \\
75.4 \\
72.7 \\
72.6\end{array}$ & $\begin{array}{r}8.5 \\
8.5 \\
11.9 \\
24.6 \\
23\end{array}$ & $\begin{array}{l}\text { August } 2009 \\
\text { June-August } 2008 \\
\text { July 2010-2011 } \\
\text { August 1993-2000 } \\
\text { July 1991-1995, } \\
\text { August 1991-1995, } \\
\text { July-August 2003-2007 }\end{array}$ & $\begin{array}{r}23 \pm 7 \\
19 \pm 6 \\
11 \pm 4 \\
25 \pm 9 \\
22 \pm 8 \\
17 \pm 4 \\
25^{*}\end{array}$ & $\begin{array}{l}\text { Present study } \\
\text { David and Nair (2011) } \\
\text { Nishanth et al. (2014) } \\
\text { Naja et al. (2003) } \\
\text { Lal et al. (2000); } \\
\text { Srivastava et al. (2012) }\end{array}$ \\
\hline \multicolumn{6}{|l|}{ Central India } \\
\hline Anantapur & 77.65 & 14.62 & July 2009 & $30 \pm 2$ & Reddy et al. (2011) \\
\hline \multicolumn{6}{|l|}{ Eastern coast of India } \\
\hline Bhubaneswar & 86.4 & 20.5 & June-August 2011-2012 & $29 \pm 6$ & Mahapatra et al. (2014) \\
\hline \multicolumn{6}{|l|}{ Bay of Bengal } \\
\hline Bay of Bengal & $80.3-90.1$ & $11-21.1$ & July-August 2009 & $30 \pm 7$ & Present study \\
\hline
\end{tabular}

* Boundary layer $\mathrm{O}_{3}$ over the Arabian Sea.

vestigation is the additional $\mathrm{O}_{3}$ over the $\mathrm{BoB}$ produced by en route photochemistry, daytime $\mathrm{O}_{3}$ values at Thiruvananthapuram are therefore compared with all the observations over the BoB. The average mixing ratio observed over the BoB during monsoon season for 16 July-17 August 2009 was $30 \pm 7 \mathrm{nmol} \mathrm{mol}^{-1}$, which was $\sim 7 \mathrm{nmol} \mathrm{mol}^{-1}$ higher than the Arabian Sea air mass. This additional amount of $\sim 7 \mathrm{nmol} \mathrm{mol}^{-1}$ could be attributed to the effects of regional and en route photochemical $\mathrm{O}_{3}$ production. Net $\mathrm{O}_{3}$ production rate in the outflow is estimated to be in the range of $1.5-4 \mathrm{nmol} \mathrm{mol}^{-1} \mathrm{day}^{-1}$. Note that the $\mathrm{O}_{3}$ mixing ratio is reported to be $\sim 30 \pm 2 \mathrm{nmol} \mathrm{mol}^{-1}$ during July 2009 over Anantapur, a rural site in central India, indicating the enhancement due to regional $\mathrm{O}_{3}$ production. As shown in Table 2, while average $\mathrm{O}_{3}$ mixing ratios over the west coast of India and the Arabian Sea are in the range of 9$25 \mathrm{nmol} \mathrm{mol}^{-1}$ during the monsoon season, the average $\mathrm{O}_{3}$ mixing ratio is $\sim 30 \mathrm{nmol} \mathrm{mol}^{-1}$ over the central Indian station and the BoB.

$\mathrm{O}_{3}$ mixing ratios were $27 \pm 3$ and $28 \pm 5 \mathrm{nmol} \mathrm{mol}^{-1}$ for 21 July 2009 and 15 August 2009, for which back trajectories (not shown here) crossed Thiruvananthapuram on 20 July and 13 August 2009, with daytime $\mathrm{O}_{3}$ values of $23 \pm 6$ and $25 \pm 6 \mathrm{nmol} \mathrm{mol}^{-1}$, respectively. The difference of 3$4 \mathrm{nmol} \mathrm{mol}^{-1}$ between $\mathrm{O}_{3}$ mixing ratios over the $\mathrm{BoB}$ and Thiruvananthapuram represents the en route photochemical production of $\mathrm{O}_{3}$ in the air masses toward the observation points over the $\mathrm{BoB}$. It is further found that the air masses were typically below $700 \mathrm{~m}$ and generally within the marine boundary layer (e.g. mean boundary layer height $\sim 897 \mathrm{~m}$ during winter over the BoB; Subrahamanyam et al., 2012). The enhancements in $\mathrm{O}_{3}$ are attributed here to in situ photochemical build-up while moving towards the BoB, which has been noted in previous experiments and model simulations (e.g. Lal and Lawrence, 2001; Ojha et al., 2012).

CO showed a sharp enhancement (denoted with red arrows in Fig. 4b) on 7 and 11 August 2009, coinciding with a longer residence time over the Indian region. Figure 5 shows backward air mass trajectories above the measurement locations, along with the distribution of anthropogenic CO emissions from the INTEX-B inventory, representative of the year 2006. The air masses over the BoB are found to be influenced by emission hotspots (corresponding emission of $250-350 \mathrm{~mol} \mathrm{~km}^{-2} \mathrm{~h}^{-1}$ ). The air masses took about half a day to be transported from the emission hotspot to the observation location over the $\mathrm{BoB}$. The $\mathrm{CO}$ mixing ratio measured at Bhubaneswar $\left(20.30^{\circ} \mathrm{N} ; 85.83^{\circ} \mathrm{E}\right)$, a station within the hotspot region, is $\sim 251 \pm 58 \mathrm{nmol} \mathrm{mol}^{-1}$ during the monsoon season (June-August 2011-2012; Mahapatra et al., 2014), with the elevated CO emissions in the Bhubaneswar region being attributed to industrial activities. The higher $\mathrm{CO}$ mixing ratio $\sim 200 \mathrm{nmol} \mathrm{mol}^{-1}$ is in line 


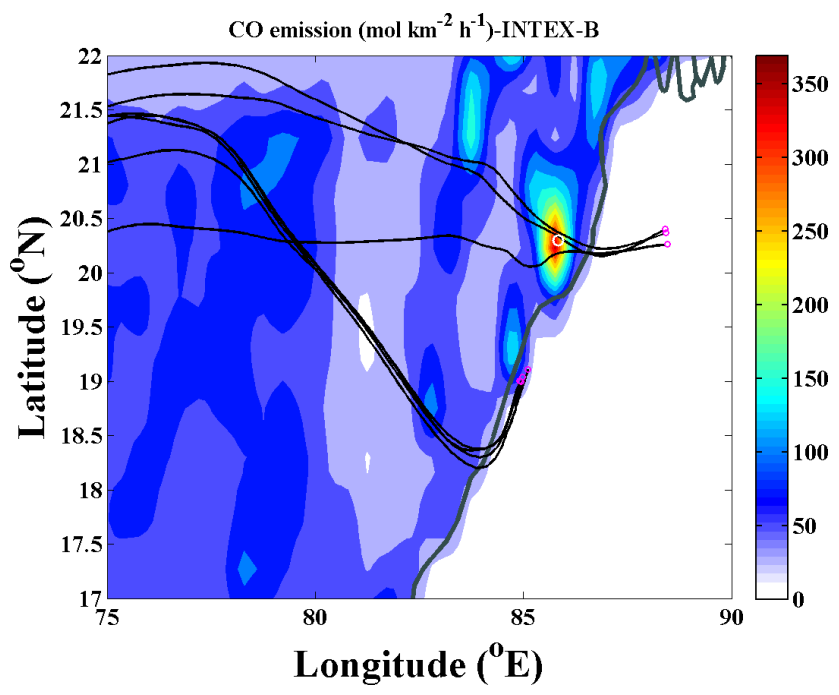

Figure 5. Backward air mass trajectories (black curves) $500 \mathrm{~m}$ above the location of higher $\mathrm{CO}$ observations as marked by red arrows in Fig. 4b during 7 and 11 August 2009. The background colour map shows the spatial distribution of anthropogenic CO emissions over the Indian region for the year 2006 from INTEX-B inventory. The small circles in magenta represent the points where observations were made, as well as the end point of trajectories. The white circle over the hotspot region denotes an observational site, Bhubaneswar.

with the monsoonal values observed at Bhubaneswar. The $\mathrm{CO}$ mixing ratios around $150 \mathrm{nmol} \mathrm{mol}^{-1}$ were sampled on 11 August 2009 near the coastal source regions. Additionally, CO mixing ratios over central $\mathrm{BoB}\left(101 \mathrm{nmol} \mathrm{mol}^{-1}\right)$ were only slightly higher than those over northern $\mathrm{BoB}$ $\left(95 \mathrm{nmol} \mathrm{mol}^{-1}\right)$. It is suggested that this is partially due to higher emissions over southern India against the shorter residence of air masses over land and the relatively longer lifetime of CO.

The mixing ratios of surface $\mathrm{CH}_{4}$ were higher in the air masses from central/northern Indian over northern BoB $\left(1.86 \pm 0.12 \mu \mathrm{mol} \mathrm{mol}^{-1}\right)$ as compared to those in the air masses from southern India $\left(1.72 \pm 0.14 \mu \mathrm{mol} \mathrm{mol}^{-1}\right)$. As $\mathrm{CH}_{4}$ is a relatively well-mixed trace gas, the average values over the tropospheric column approximates the uniform mixing ratio within the troposphere (Seinfeld and Pandis, 2006). The monthly column-averaged tropospheric $\mathrm{CH}_{4}$, retrieved from SCIAMACHY, for August 2009 shows (Fig. 6) higher values around $1.85 \mu \mathrm{mol} \mathrm{mol}^{-1}$ over central/northern India as compared to that of southern India $\left(\sim 1.80 \mu \mathrm{mol} \mathrm{mol}^{-1}\right)$. The higher tropospheric $\mathrm{CH}_{4}$ over the central/northern Indian landmass during the summer monsoon season has been also reported by Kavitha and Nair (2016). The observed higher $\mathrm{CH}_{4}$ over the northern $\mathrm{BoB}$ are attributed to the influences of emissions from central/northern Indian regions as also suggested by backward trajectories. Owing to the longer lifetime of $\mathrm{CH}_{4}$, diffusion of $\mathrm{CH}_{4}$ from a hotspot re-

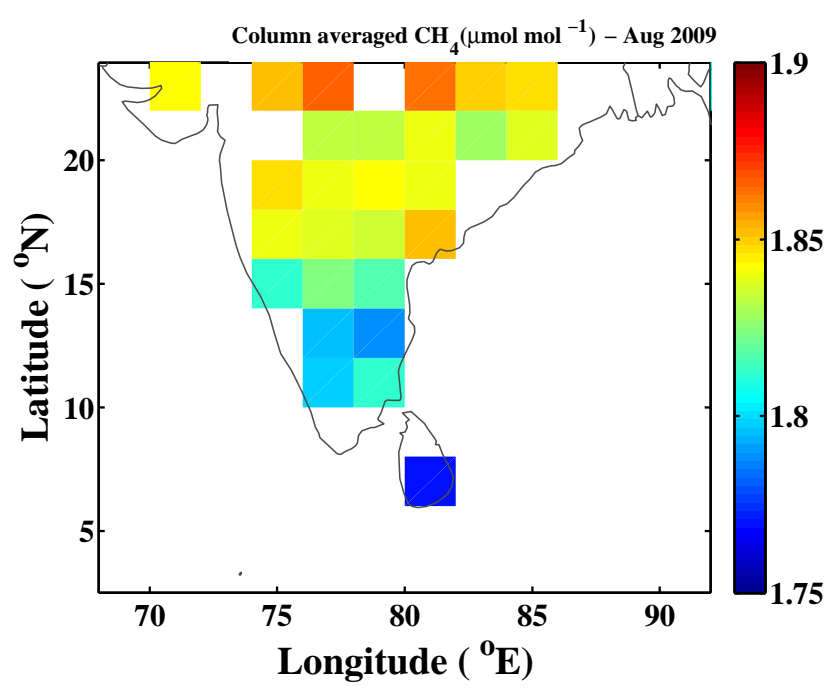

Figure 6. Spatial distribution of column-averaged $\mathrm{CH}_{4}$ for the month of August 2009 as obtained from SCIAMACHY.

gion over the eastern IGP to northern $\mathrm{BoB}$ might be the other source of higher $\mathrm{CH}_{4}$ levels over northern $\mathrm{BoB}$ during summer monsoon season. An emission inventory analysis by sector over the hotspot region (i.e. eastern IGP) indicates that these higher $\mathrm{CH}_{4}$ emissions are associated with rice cultivation, waste treatment, and livestock. The correlation between the in situ $\mathrm{CH}_{4}$ measurements and the retrievals from the satellite instrument (AIRS - Atmospheric Infrared Sounder) was found to be statistically insignificant (not shown), which highlights a need of more such in situ measurements in this region to validate the satellite products, especially during the summer monsoon.

\subsection{WRF-Chem simulations}

WRF-Chem simulations, as described in Sect. 4, are used to evaluate the performance of the model in reproducing the measurements and to investigate the underlying processes that caused the observed variabilities in $\mathrm{O}_{3}$ and $\mathrm{CO}$. A comparison between model-simulated and measured meteorological parameters shows only small mean biases, such as $-1.9 \mathrm{hPa}$ in pressure, $-0.6^{\circ} \mathrm{C}$ in temperature, and $-1.1 \%$ in relative humidity (Table 3 ). Figure $4 \mathrm{~b}-\mathrm{c}$ compare WRFChem simulated $\mathrm{O}_{3}$ and $\mathrm{CO}$ with in situ measurements taken along the cruise track. WRF-Chem is found to reproduce the observed variations of $\mathrm{O}_{3}$ and $\mathrm{CO}$ over the $\mathrm{BoB}$ during the summer monsoon season with an overestimation of absolute $\mathrm{O}_{3}$ levels by $1.9 \mathrm{nmol} \mathrm{mol}^{-1}$ (i.e. $\sim 6 \%$ of averaged $\mathrm{O}_{3}$ value, $29.7 \mathrm{nmol} \mathrm{mol}^{-1}$ ) and absolute $\mathrm{CO}$ levels by $18 \mathrm{nmol} \mathrm{mol}^{-1}$ (i.e. $\sim 16 \%$ of averaged $\mathrm{CO}$ value, $96 \mathrm{nmol} \mathrm{mol}^{-1}$ ). It should be noted that the average CO mixing ratio of $96 \mathrm{nmol} \mathrm{mol}^{-1}$ is slightly higher than its actual value, as data points below the detection limit of the instrument are discarded. Biases in the model simulations can be 
Table 3. A comparison of mean values from observations with model-simulated parameters along with the mean bias. The squared correlation coefficients correspond to the linear regression analysis between daily averaged in situ and simulated parameters.

\begin{tabular}{lrrrr}
\hline Parameter & Observation & Model (WRF-Chem) & Mean bias & $R^{2}$ \\
\hline Pressure $(\mathrm{hPa})$ & $1001.3 \pm 2.1$ & $999.4 \pm 2.2$ & -1.9 & 0.93 \\
Temperature $\left({ }^{\circ} \mathrm{C}\right)$ & $29.3 \pm 0.9$ & $28.7 \pm 0.6$ & -0.6 & 0.13 \\
Relative humidity $(\%)$ & $87.9 \pm 4.2$ & $86.8 \pm 2.8$ & -1.1 & 0.36 \\
$\mathrm{O}_{3}\left(\mathrm{nmol} \mathrm{mol}{ }^{-1}\right)$ & $29.7 \pm 6.8$ & $31.6 \pm 6.6$ & 1.9 & 0.58 \\
$\mathrm{CO}\left(\mathrm{nmol} \mathrm{mol}^{-1}\right)$ & $96 \pm 25$ & $114 \pm 30$ & 18 & 0.19 \\
\hline
\end{tabular}

attributed to the uncertainties in the simulated meteorology and in the emission datasets; however, in the present study, the model fields are used mainly to investigate temporal variations rather than absolute mixing ratios. The squared correlation coefficients between the daily averaged in situ measured and simulated $\mathrm{O}_{3}$ and $\mathrm{CO}$ are 0.58 and 0.19 , respectively. The higher value of the squared correlation coefficient for $\mathrm{O}_{3}$ demonstrates WRF-Chem's ability to reproduce the observed broad features in surface $\mathrm{O}_{3}$ over the $\mathrm{BoB}$. Note that the sharp reductions that caused very low $\mathrm{O}_{3}$ during rainfall episodes are not captured by WRF-Chem, except during the event of 10-11 August 2009. This will be discussed in detail in Sect. 5.3. WRF-Chem simulated $\mathrm{O}_{3}$ has also been evaluated against several surface observations in India previously (Kumar et al., 2012b). Modelled $\mathrm{O}_{3}$ was found to be within $1 \sigma$ standard deviation of mean from observations at Gadanki in the southern India during summer monsoon (Ojha et al., 2016). At Thumba also, model-simulated $\mathrm{O}_{3}$ variations correlated reasonably with measurements $\left(R^{2}=0.6\right)$. More information on evaluation of WRF-Chem simulations of $\mathrm{O}_{3}$ and $\mathrm{CO}$ over India can be found elsewhere (e.g. Kumar et al., 2012b; Ojha et al., 2016).

An additional simulation was conducted by switching off the anthropogenic emissions over the model domain (Fig. 4b-c; dotted blue curves). Mean $\mathrm{O}_{3}\left(17.7 \mathrm{nmol} \mathrm{mol}^{-1}\right)$ is found to be lower by 14 with smaller variability of $2.4 \mathrm{nmol} \mathrm{mol}^{-1}$ compared to standard WRF-Chem simulation. Similarly, also the mean CO level is lower by 36 with smaller variability of $4.9 \mathrm{nmol} \mathrm{mol}^{-1}$. This shows that enhanced levels and observed variability in $\mathrm{O}_{3}$ and $\mathrm{CO}$ mixing ratios over $\mathrm{BoB}$ are attributable to the regional anthropogenic emissions.

The limited collocated measurements showed en route $\mathrm{O}_{3}$ production rate of $1.5-4 \mathrm{nmol} \mathrm{mol}^{-1}$ day $^{-1}$, as discussed in Sect. 5.1. Here, the $\mathrm{O}_{3}$ production rate is estimated by analysing the model-simulated $\mathrm{O}_{3}$ mixing ratios along the air mass trajectories ending at few representative locations over the BoB (Fig. 7a). The model-simulated chemical evolution of air parcels clearly shows an increase in the $\mathrm{O}_{3}$ mixing ratios towards the marine region of $\mathrm{BoB}$. The temporal variations of $\mathrm{O}_{3}$ mixing ratio averaged corresponding all the trajectories shown in Fig. 7a is shown as a box plot in Fig. 7b. A linear regression analysis (blue curve in Fig. 7b)
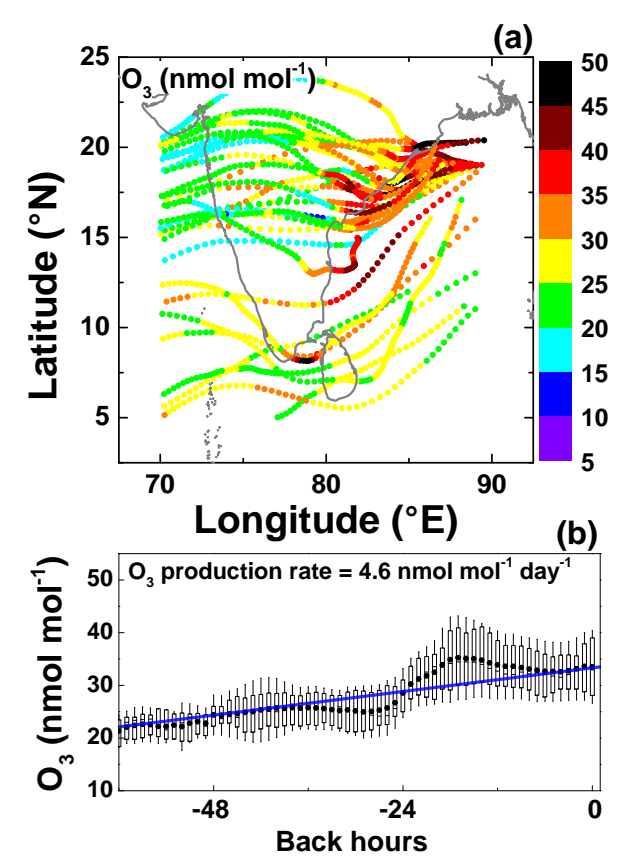

Figure 7. (a) WRF-Chem simulated $\mathrm{O}_{3}$ along the air mass trajectories ending over a few representative locations over the BoB. (b) Variation of $\mathrm{O}_{3}$ mixing ratios with time along the trajectories as shown in (a). In box plot, the black dots and lines inside the box represent the mean and median of the data, respectively. While the lower and upper edges of boxes represent the 25 th and 75 th percentiles, respectively, the whiskers represent standard deviations.

is used to estimate the mean en route $\mathrm{O}_{3}$ production rate of $\sim 4.6 \mathrm{nmol} \mathrm{mol}^{-1} \mathrm{day}^{-1}$ in the outflow. The enhancement in average $\mathrm{O}_{3}$ over the $\mathrm{BoB}$ as compared to the continental Indian region is also shown in the Fig. 2d, averaged for the study period.

\subsection{Ozone variations during rainfall events}

An interesting phenomenon observed during the CTCZ experiment is the abrupt reduction in $\mathrm{O}_{3}$ mixing ratios that accompanied the onset of heavy rainfall, despite the low solubility of $\mathrm{O}_{3}$ in water. In this section the possible causes of these low- $\mathrm{O}_{3}$ events during rainfall are investigated. 

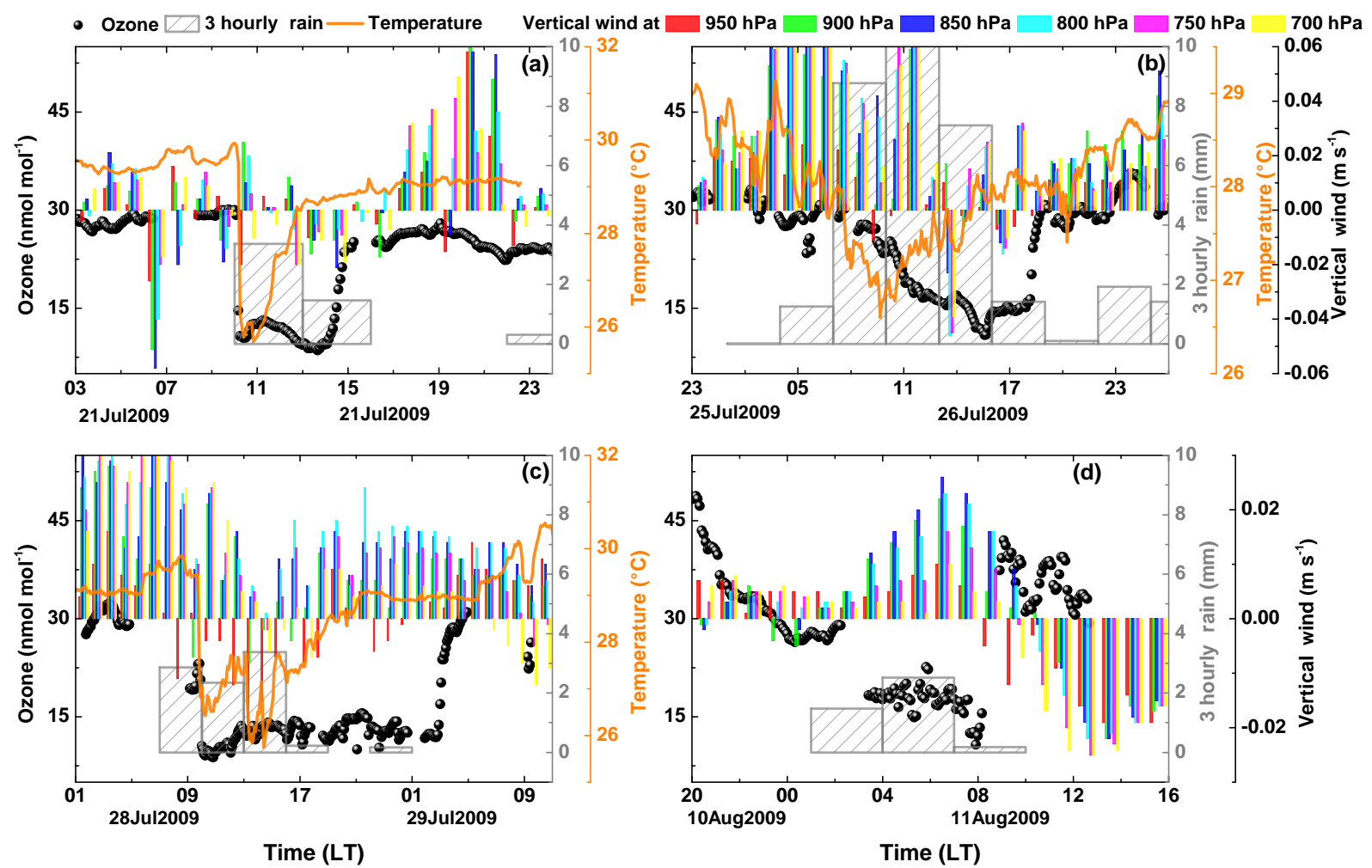

Figure 8. Surface $\mathrm{O}_{3}$ (black dots) along with temperature (orange curve) and $3 \mathrm{~h}$ rainfall (grey vertical bar) during the four events of sharp decline in $\mathrm{O}_{3}(\mathbf{a}-\mathbf{d})$ as marked in Fig. 4c. Colours indicate the vertical wind as simulated by WRF-Chem.

Table 4. A comparison of average mixing ratios of surface trace gases measured over northern $\mathrm{BoB}\left(81-91^{\circ} \mathrm{E}, 16-21.5^{\circ} \mathrm{N}\right)$ and central $\mathrm{BoB}$ $\left(80-91^{\circ} \mathrm{E}, 11-16^{\circ} \mathrm{N}\right)$ in different seasons as measured during different experiments. The range of mixing ratios (i.e. minima-maxima) is given in the brackets.

\begin{tabular}{|c|c|c|c|c|c|c|c|c|}
\hline $\begin{array}{l}\text { Study } \\
\text { period }\end{array}$ & $\begin{array}{l}\text { Name of } \\
\text { experiment }\end{array}$ & Reference & 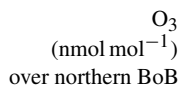 & $\begin{array}{r}\mathrm{O}_{3} \\
\left(\mathrm{nmol} \mathrm{mol}{ }^{-1}\right) \\
\text { over central BoB }\end{array}$ & $\begin{array}{r}\mathrm{CO} \\
\left(\mathrm{nmol} \mathrm{mol}{ }^{-1}\right) \\
\text { over northern BoB }\end{array}$ & $\begin{array}{r}\mathrm{CO} \\
\left(\mathrm{nmol} \mathrm{mol}{ }^{-1}\right) \\
\text { over central BoB }\end{array}$ & 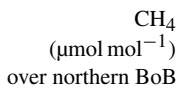 & $\begin{array}{r}\mathrm{CH}_{4} \\
\left(\mu \mathrm{mol} \mathrm{mol}^{-1}\right) \\
\text { over central BoB }\end{array}$ \\
\hline $\begin{array}{l}\text { December 2008- } \\
\text { January } 2009\end{array}$ & W_ICARB & David et al. (2011) & $\begin{array}{r}63.0 \pm 4.7 \\
(50.8-73.8)\end{array}$ & $\begin{array}{r}40.9 \pm 6.7 \\
(27.7-63.5)\end{array}$ & $\begin{array}{r}302 \pm 68 \\
(140-450)\end{array}$ & $\begin{array}{l}188 \pm 53 \\
(50-320)\end{array}$ & No data & No data \\
\hline February 2003 & BOBEX-II & Lal et al. (2007) & $\begin{array}{r}\sim 34.1 \\
(15.8-50.4)\end{array}$ & $\begin{array}{r}\sim 26.8 \\
(13.9-35.0)\end{array}$ & $\begin{array}{r}\sim 238 \\
(187-292)\end{array}$ & $\begin{array}{r}\sim 192 \\
(159-224)\end{array}$ & $\begin{array}{r}\sim 1.77 \\
(1.70-1.85)\end{array}$ & $\begin{array}{r}\sim 1.73 \\
(1.68-1.77)\end{array}$ \\
\hline $\begin{array}{l}\text { February- } \\
\text { March } 2001\end{array}$ & BOBEX-I & Lal et al. (2006) & $\begin{array}{r}\sim 23.8 \\
(16.1-38.3)\end{array}$ & $\begin{array}{r}\sim 38.0 \\
(19.4-62.9)\end{array}$ & $\begin{array}{r}\sim 194 \\
(165-235)\end{array}$ & $\begin{array}{r}\sim 227 \\
(97-339)\end{array}$ & $\begin{array}{r}\sim 1.94 \\
(1.89-2.02)\end{array}$ & $\begin{array}{r}\sim 1.91 \\
(1.74-2.06)\end{array}$ \\
\hline March-April 2006 & ICARB & $\begin{array}{l}\text { Nair et al. (2011); } \\
\text { Srivastava et al. (2012) }\end{array}$ & $\begin{array}{r}27.4 \pm 2.9 \\
(21.4-32.6)\end{array}$ & $\begin{array}{l}13.4 \pm 4.2 \\
(3.1-24.6)\end{array}$ & $\begin{array}{r}\sim 189 \\
(157-235)\end{array}$ & $\begin{array}{r}\sim 132 \\
(96-167)\end{array}$ & $\begin{array}{r}\sim 1.84 \\
(1.80-1.88)\end{array}$ & $\begin{array}{r}\sim 1.80 \\
(1.75-1.84)\end{array}$ \\
\hline July-August 2009 & CTCZ & Present Study & $\begin{array}{r}30.0 \pm 6.9 \\
(8.50-54.1)\end{array}$ & $\begin{array}{l}27.5 \pm 5.0 \\
(8.8-40.5)\end{array}$ & $\begin{array}{r}95 \pm 25^{*} \\
(50-200)^{*}\end{array}$ & $\begin{array}{l}101 \pm 27^{*} \\
(50-157)^{*}\end{array}$ & $\begin{array}{l}1.86 \pm 0.12 \\
(1.62-2.15)\end{array}$ & $\begin{array}{l}1.72 \pm 0.14 \\
(1.57-1.96)\end{array}$ \\
\hline $\begin{array}{l}\text { September- } \\
\text { October } 2002\end{array}$ & BOBPS & Sahu et al. (2006) & $\begin{array}{r}\sim 27.3 \\
(17.8-33.8)\end{array}$ & $\begin{array}{r}\sim 30.6 \\
(22.5-35.2)\end{array}$ & $\begin{array}{r}\sim 152 \\
(109-179)\end{array}$ & $\begin{array}{r}\sim 141 \\
(108-211)\end{array}$ & $\begin{array}{r}\sim 1.79 \\
(1.72-1.86)\end{array}$ & $\begin{array}{r}\sim 1.73 \\
(1.68-1.80)\end{array}$ \\
\hline November 2010 & - & Mallik et al. (2013) & $\begin{array}{r}\sim 46.0 \\
(26.7-59.6)\end{array}$ & $\begin{array}{r}\sim 38.7 \\
(17.8-60.8)\end{array}$ & $\begin{array}{r}\sim 223 \\
(131-280)\end{array}$ & $\begin{array}{r}\sim 188 \\
(42-266)\end{array}$ & $\begin{array}{r}\sim 1.95 \\
(1.85-2.06)\end{array}$ & $\begin{array}{r}\sim 1.79 \\
(1.67-1.93)\end{array}$ \\
\hline
\end{tabular}

${ }^{*} \mathrm{CO}$ mixing ratios below the detection limit (i.e. $50 \mathrm{nmol} \mathrm{mol}^{-1}$ ) are not considered in the analysis.

Figure 8 shows variations in $\mathrm{O}_{3}$ (black circles) mixing ratios, surface temperature (orange curve), TRMM retrieved rainfall (thick grey vertical bars), and WRF-Chem simulated vertical winds at pressure levels ranging from 950 to $750 \mathrm{hPa}$ (coloured bars) during four such events on 21, 26, and 28-29 July and on 10-11 August 2009. As high time resolution in situ measurements of rainfall were not available aboard ship, Fig. 8 therefore uses $3 \mathrm{~h}$ rainfall retrievals from the TRMM, co-located with $\mathrm{O}_{3}$ measurements. During these events, $\mathrm{CO}$ mixing ratios also show a reduction of about $\sim 56 \mathrm{nmol} \mathrm{mol}^{-1}$, with observed values falling below the detection limit of the instrument during the first event of 21 July 2009 (not shown). Although CO measurements are not available for the second and third event, during the fourth event (10-11 August 2009) CO mixing ratios showed an enhancement due to transport from strong source regions 
(see Sect. 5.1). While the first three low- $\mathrm{O}_{3}$ events are not captured by WRF-Chem (Fig. 4c), the fourth event is reproduced.

Wet scavenging does not directly reduce $\mathrm{O}_{3}$, as its water solubility is low; as a result, some dynamic process could be responsible for the observed reductions in $\mathrm{O}_{3}$ during rainfall. Air masses could undergo downdrafts during heavy rainfall (Kishore Kumar et al., 2005) through air drag by the falling rain drops and in mesoscale subsidence that compensates convective updrafts. We suggest that, in the presence of $\mathrm{O}_{3}$-poor air mass aloft, a downdraft would result in reductions in surface $\mathrm{O}_{3}$ mixing ratios. An opposite scenario leading to $\mathrm{O}_{3}$ enhancement could take place if downdrafts bring mid-tropospheric air, where typically $\mathrm{O}_{3}$ is higher than at surface. The model-simulated meteorology shows occurrences of downdrafts at different pressure levels during the first three events on 21, 26, and 28-29 July (Fig. 8a-c), which is further corroborated with measurements of air temperature aboard. Downdrafts of free-tropospheric air could lead to a reduction in near-surface temperature by as much as $10^{\circ} \mathrm{C}$ within a few minutes (Ahrens, 2009). Air temperature measured aboard ship showed a sharp decrease of $2-4{ }^{\circ} \mathrm{C}$, coinciding with the first three low- $\mathrm{O}_{3}$ events (Fig. $8 \mathrm{a}-\mathrm{c}$ ). The reductions in temperature caused by downdrafts are generally short-lived (Ahrens, 2009), as is confirmed in the case of these events (Fig. 8a-c).

Model-simulated vertical winds and variations in air temperature suggest that downdrafts did occur during the first three rainfall events. As in situ measurements of $\mathrm{O}_{3}$ vertical profiles are not available over the BoB during the summer monsoon season, the observations taken at Thumba, Thiruvananthapuram, in the southern Indian region are used as a case study to investigate this hypothesis. For general details of the typical diurnal and seasonal variations of $\mathrm{O}_{3}$ at Thumba, please see Nair et al. (2002), David and Nair (2011), and Girach et al. (2012). Figure 9a shows the temporal variation in surface $\mathrm{O}_{3}$ on 15 July 2011 at Thumba, along with $5 \mathrm{~min}$ accumulated rainfall. Here, surface $\mathrm{O}_{3}$ is observed to decline from 25 to $13 \mathrm{nmol} \mathrm{mol}^{-1}$ within $15-$ $20 \mathrm{~min}$, coinciding with the occurrence of intense rainfall (3.5- $0.5 \mathrm{~mm}$ rain over a period of $5 \mathrm{~min}$ ). Measurements of the $\mathrm{O}_{3}$ vertical profile are not available for this day due to the rainy conditions; a profile measured on 28 July 2011 is therefore shown in Fig. 9b. This profile has lower $\mathrm{O}_{3}$ mixing ratios aloft $\left(\sim 22 \mathrm{nmol} \mathrm{mol}^{-1}\right.$ at $\left.\sim 1 \mathrm{~km}\right)$ than near the surface $\left(\sim 42 \mathrm{nmol} \mathrm{mol}^{-1}\right)$. The observed mixed layer height is about $0.15-0.6 \mathrm{~km}$ over Thumba, Thiruvananthapuram (Anurose et al., 2016), during July 2011; above this height, $\mathrm{O}_{3}$ mixing ratios sharply decrease with altitude. The present case study suggests the presence of $\mathrm{O}_{3}$-poor air masses aloft than those near the surface over the south Indian region during summer monsoon. With an $\mathrm{O}_{3}$ distribution as observed in the present case study at Thumba, the downdraft during intense rainfall could lead to the mixing of free-tropospheric
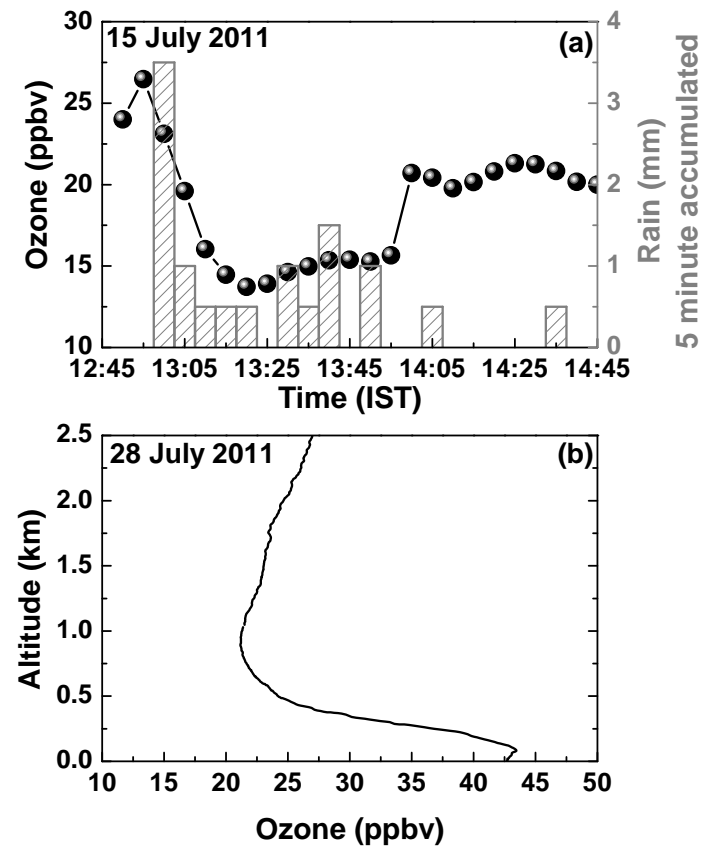

Figure 9. (a) Temporal variation in surface $\mathrm{O}_{3}$ mixing ratio (black dots) along with $5 \mathrm{~min}$ accumulated rainfall (grey vertical bars) over Thumba, Thiruvananthapuram (location of the site shown in Fig. 1), on 15 July 2011. (b) Vertical profile of $\mathrm{O}_{3}$ mixing ratio over Thumba, Thiruvananthapuram, as measured on 28 July 2011.

air with near-surface air or to the replacement of surface air with free-tropospheric $\mathrm{O}_{3}$-poor air.

Although air temperature measurements could not be made during the fourth event (10-11 August 2009) due to a technical problem, model meteorology does not indicate a downdraft during this event (Fig. 8d), indicating the dominance of a different process. As WRF-Chem simulated $\mathrm{O}_{3}$ variability is in good agreement with observations during this event, various tendency terms (Barth et al., 2012) from WRFChem are used to investigate the relative influences of different processes. The variations in instantaneous values for horizontal advection tendency, vertical advection tendency, and net tendency (i.e. the sum of chemical, vertical mixing, convective, vertical advection, and horizontal advection), along with modelled $\mathrm{O}_{3}$ over the two locations during the event, are shown in Fig. 10. The tendency values shown here are derived by subtracting the accumulated tendencies at $(n-1)$ th hour from the accumulated tendency at $n$th hour. The vertical dotted lines show the time of a low- $\mathrm{O}_{3}$ event.

Both the horizontal and net tendencies (Fig. 10b-c, e-f) show negative values, indicating that they are contributing towards a reduction in $\mathrm{O}_{3}$ mixing ratios (Fig. 10a, d). However, as the time of the event approaches, it is the horizontal advection tendency term that is significantly negative (Fig. 10c, f), while other terms are small and close to zero. Horizontal advection is therefore suggested to dominate during the low$\mathrm{O}_{3}$ event of 10-11 August 2009. The influence of horizon- 

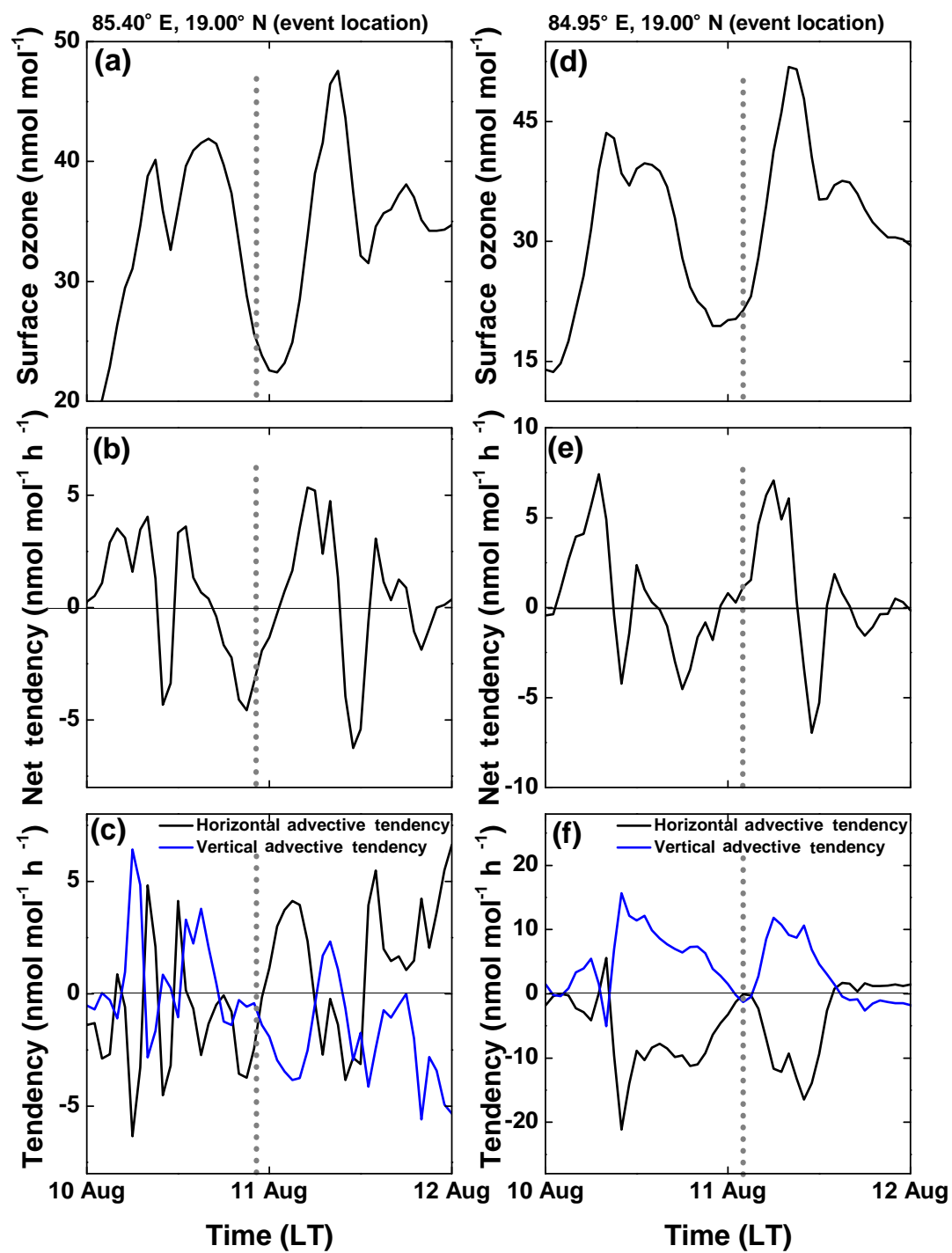

Figure 10. Time series of surface $\mathrm{O}_{3}$ (a) and various tendency terms (b and c) over the event location during the fourth low-O $\mathrm{O}_{3}$ event, as obtained from WRF-Chem simulations. (d)-(f) are the same as (a)-(c), but for another location during the same event. These two event locations are also marked by triangles in Fig. 11. Vertical dotted line shows the time of the event in the in situ observations of surface $\mathrm{O}_{3}$ over the indicated locations.

tal advection on $\mathrm{O}_{3}$ during this event is shown more clearly in Fig. 11, which shows the spatial distribution of $\mathrm{O}_{3}$ and CO from WRF-Chem before the event (16:00 and 19:00 UT) and during the event (22:00 UT) on 10 August 2009. The white triangles show the two locations where the event was observed. During 16:00 and 19:00 UT, a patch of high $\mathrm{O}_{3}$ mixing ratios $\left(35 \mathrm{nmol} \mathrm{mol}^{-1}\right.$ and higher) is seen to be distributed over a large region surrounding the measurement location. This large patch of elevated $\mathrm{O}_{3}$ mixing ratios is horizontally advected eastward from 16:00 to 19:00 and then towards 22:00 UT (event time). As a result of this rapid advection, the high- $\mathrm{O}_{3}$ air masses are transported from the coastal regions to deeper into the $\mathrm{BoB}$; by the time they reached the location of observation, $\mathrm{O}_{3}$ mixing ratios are observed to be lower (25-35 nmol mol${ }^{-1}$ ) during the event time (22:00 UT). A patch of higher levels of $\mathrm{CO}\left(\sim 300 \mathrm{nmol} \mathrm{mol}^{-1}\right)$ was also found to be distributed across the east coast of the Indian region. Transport and dilution of this $\mathrm{CO}$ patch is, however, less pronounced than the high- $\mathrm{O}_{3}$ air masses, possibly due to the relatively longer lifetime of $\mathrm{CO}$. Thus, in a nutshell, the horizontal advection played a key role in transporting $\mathrm{O}_{3}$-rich air masses deeper into the $\mathrm{BoB}$ region, while it diluted $\mathrm{O}_{3}$ levels near the coastal regions in southern India during the fourth event. 

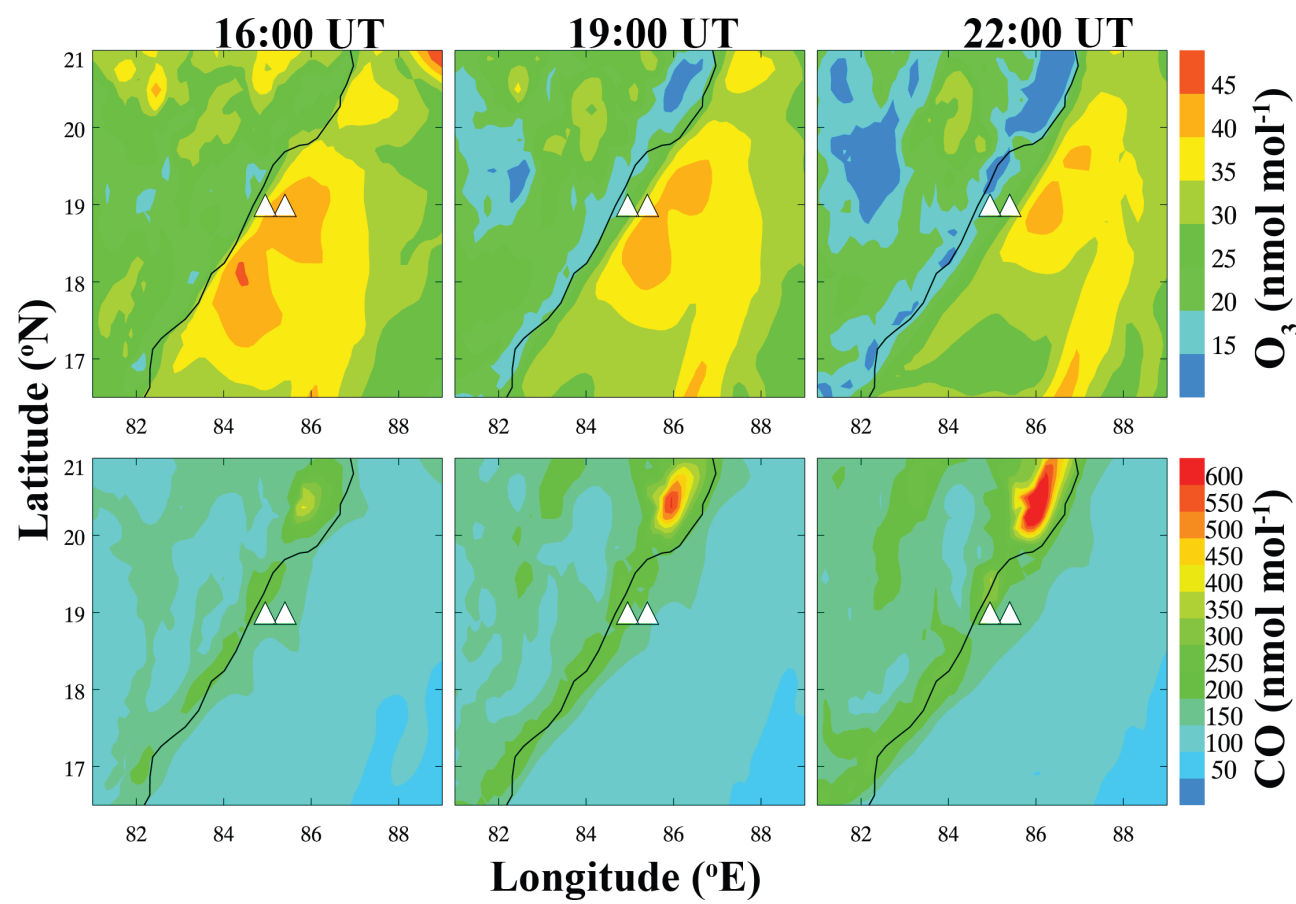

Figure 11. Spatial distribution of surface $\mathrm{O}_{3}$ (top panel) and $\mathrm{CO}$ (bottom panel) at 16:00 and 19:00 UT on 10 August 2009, both prior to and during the fourth event, which took place $22: 00 \mathrm{UT}$ on 10 August 2009 . White triangles show two locations $\left(85.40^{\circ} \mathrm{E}, 19.00^{\circ} \mathrm{N} ; 84.95^{\circ} \mathrm{E}\right.$, $19.00^{\circ} \mathrm{N}$ ) corresponding to the event.

\subsection{Seasonal variation in trace gases over the BoB}

In this section, the monsoon-time measurements of $\mathrm{O}_{3}$ taken in the present study are combined with data from previous campaigns (see Table 4) to investigate the seasonal variation in $\mathrm{O}_{3}$ over the $\mathrm{BoB}$ (Fig. 12). $\mathrm{O}_{3}, \mathrm{CO}$, and $\mathrm{CH}_{4}$ mixing ratios are averaged over northern $\left(81-91^{\circ} \mathrm{E}, 16-21.5^{\circ} \mathrm{N}\right)$ and central $\left(80-91^{\circ} \mathrm{E}, 11-16^{\circ} \mathrm{N}\right) \mathrm{BoB}$ regions.

Overall, higher $\mathrm{O}_{3}$ mixing ratios are present over both northern and central $\mathrm{BoB}$ during the winter, while lower $\mathrm{O}_{3}$ levels are observed during the spring-summer (with more scatter in the data over central $\mathrm{BoB}$ ). The $\mathrm{O}_{3}$ seasonal amplitude (i.e. the range from maxima to minima) is estimated to be $\sim 39$ over northern $\mathrm{BoB}$ and $\sim 27 \mathrm{nmol} \mathrm{mol}^{-1}$ over central $\mathrm{BoB}$. The monsoonal surface $\mathrm{O}_{3}$ mixing ratios $\left(\sim 30 \pm 7 \mathrm{nmol} \mathrm{mol}^{-1}\right)$ are nearly half those observed during winter $\left(63 \pm 5 \mathrm{nmol} \mathrm{mol}^{-1}\right)$ over northern BoB. During December 2008-January 2009, February 2003, March 2006, and November 2010, the $\mathrm{O}_{3}$ mixing ratios were higher (by $\sim 3-22 \mathrm{nmol} \mathrm{mol}^{-1}$ ) over northern $\mathrm{BoB}$ than over central BoB. However, over the course of February 2001, $\mathrm{O}_{3}$ mixing ratios were higher over central $\mathrm{BoB}\left(\sim 38 \mathrm{nmol} \mathrm{mol}^{-1}\right)$ than over northern $\mathrm{BoB}\left(\sim 14 \mathrm{nmol} \mathrm{mol}^{-1}\right)$. In contrast, during summer monsoon season, average $\mathrm{O}_{3}$ mixing ratios are comparable or only slightly higher over northern $\mathrm{BoB}\left(30 \pm 7 \mathrm{nmol} \mathrm{mol}^{-1}\right)$ as compared to over central $\mathrm{BoB}$ $\left(27 \pm 5 \mathrm{nmol} \mathrm{mol}^{-1}\right)$.
As compared with the summer monsoon season, when $\mathrm{CO}$ mixing ratios were lower over northern $\mathrm{BoB}, \mathrm{CO}$ mixing ratios were higher during the winter, while over central $\mathrm{BoB} \mathrm{CO}$ mixing ratios were higher during the pre-monsoon season. For $\mathrm{O}_{3}$, spring-summer had the lower mixing ratios in both regions. The seasonal amplitude in $\mathrm{CO}$ mixing ratios is estimated to be $\sim 205$ over northern $\mathrm{BoB}$ and $\sim 124 \mathrm{nmol} \mathrm{mol}^{-1}$ over central BoB. The monsoonal CO mixing ratio $\left(\sim 95 \mathrm{nmol} \mathrm{mol}^{-1}\right)$ is about one-third that of the winter season $\left(302 \mathrm{nmol} \mathrm{mol}^{-1}\right.$ ) over northern BoB. During the present study, average $\mathrm{CO}$ mixing ratios were comparable over northern $\left(95 \pm 25 \mathrm{nmol} \mathrm{mol}^{-1}\right)$ and central $\mathrm{BoB}$ $\left(101 \pm 27 \mathrm{nmol} \mathrm{mol}^{-1}\right)$.

A clear inference about seasonal patterns is difficult in the case of $\mathrm{CH}_{4}$, but a tendency of lower levels towards winter can be seen. Higher mixing ratios $\sim 1.95$ $(\sim 1.91) \mu \mathrm{mol} \mathrm{mol}^{-1}$ were observed during November 2010 over northern $\mathrm{BoB}$, and during February-March 2001 over central $\mathrm{BoB}$, as compared to those from other studies. The surface $\mathrm{CH}_{4}$ observations obtained during the present study show the highest variability (i.e. the difference between maxima and minima) when compared to earlier studies: 0.53 over northern BoB and $0.39 \mu \mathrm{mol} \mathrm{mol}^{-1}$ over central BoB. This high variability is attributed to the relative source strengths over central and northern India as compared to southern India, highlighting the regional differences in $\mathrm{CH}_{4}$ variability across India (Kavitha and Nair, 2016). 

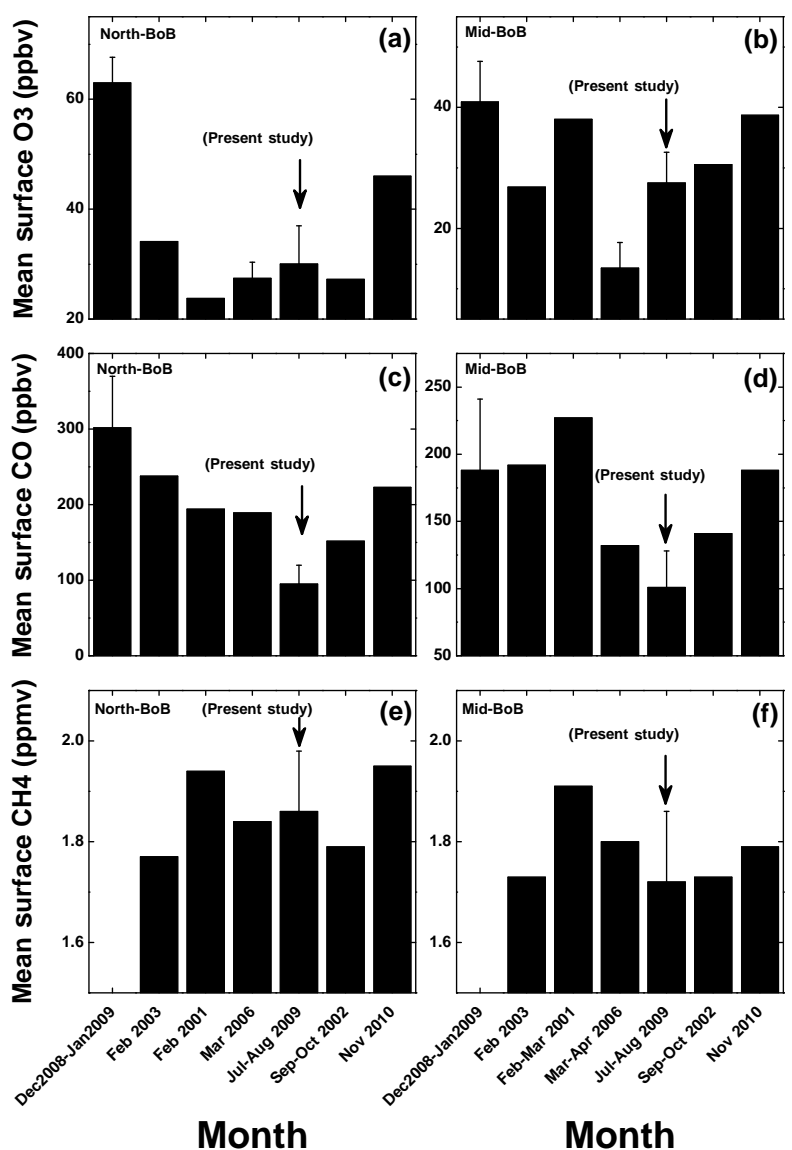

Figure 12. Seasonal variation in average $\mathrm{O}_{3}, \mathrm{CO}$, and $\mathrm{CH}_{4}$ mixing ratios over $(\mathbf{a}, \mathbf{c}, \mathbf{e})$ northern $\mathrm{BoB}$ and $(\mathbf{b}, \mathbf{d}, \mathbf{f})$ central $\mathrm{BoB}$. Except for July-August 2009 (present study period), all average values are obtained from the literature (David et al., 2011; Lal et al., 2007, 2006; Nair et al., 2011; Srivastava et al., 2012; Sahu et al., 2006; and Mallik et al., 2013). Error bars show standard deviations for respective study periods. For any points for which high-resolution measurements are not available, standard deviations are not shown.

Seasonal variations in trace gases over the BoB are attributed to seasonal changes in the meteorological conditions, emissions, and photochemistry over the South Asian region, as well as to synoptic-scale transport patterns. Wintertime stronger westerly winds transport the pollution from South Asia, including that of the Indo-Gangetic basin, to the $\mathrm{BoB}$ region. Monsoonal circulation, in contrast, carries cleaner marine air masses to the $\mathrm{BoB}$ from the oceanic regions. However, as observed during the CTCZ, polluted continental or coastal air masses can also occasionally be transported deeper over the $\mathrm{BoB}$. Intense monsoonal rainfall generally leads to wet removal of $\mathrm{O}_{3}$ precursors, while cloudy and rainy meteorological conditions suppress $\mathrm{O}_{3}$ formation. Along with the importance of monsoonal convection in cloud formation, rainfall, and uplifting the boundary layer pollution, rapid horizontal advection is also an important process during the summer monsoon, especially affecting the nearsurface variability of trace gases over the oceanic regions adjacent to India.

\section{Conclusions}

In this paper, we presented shipborne in situ measurements of $\mathrm{O}_{3}, \mathrm{CO}$, and $\mathrm{CH}_{4}$ that were carried out as a part of the CTCZ experiment over the BoB during the summer monsoon season, July-August 2009. We analysed the spatial and temporal variations in the observations and compared them with results from simulations performed with a regional chemistry transport model (WRF-Chem), as well as with observations from previous campaigns over the $\mathrm{BoB}$. The main conclusions are as follows.

These first monsoonal observations of $\mathrm{O}_{3}, \mathrm{CO}$, and $\mathrm{CH}_{4}$ show large spatio-temporal variability over the $\mathrm{BoB}$, with mixing ratios varying in the range of $\quad 8-54$ (mean: $29.7 \pm 6.8) \mathrm{nmol} \mathrm{mol}^{-1}, \quad 50-200$ (mean: $96 \pm 25) \mathrm{nmol} \mathrm{mol}^{-1}$, and 1.57-2.15 (mean: $1.83 \pm 0.14) \mu \mathrm{mol} \mathrm{mol}^{-1}$, respectively. The $\mathrm{O}_{3}$ and $\mathrm{CO}$ mixing ratios in air masses from central/northern India are slightly higher or comparable $\left(\mathrm{O}_{3}: 30 \pm 7, \mathrm{CO}\right.$ : $\left.95 \pm 25 \mathrm{nmol} \mathrm{mol}^{-1}\right)$ to those in air masses from southern India $\left(\mathrm{O}_{3}: 27 \pm 5, \mathrm{CO}: 101 \pm 27 \mathrm{nmol} \mathrm{mol}^{-1}\right)$. The $\mathrm{CH}_{4}$ mixing ratios in air masses from central/northern $\left(1.86 \pm 0.12 \mu \mathrm{mol} \mathrm{mol}^{-1}\right)$ are higher $\left(\sim 0.14 \mu \mathrm{mol} \mathrm{mol}^{-1}\right)$ compared to those in air masses from southern India $\left(1.72 \pm 0.14 \mu \mathrm{mol} \mathrm{mol}^{-1}\right)$. This could be due to higher $\mathrm{CH}_{4}$ levels over central/northern India, also found in SCIAMACHY data.

Back-trajectory analysis shows effects of long-range transport from northern or central India to northern $\mathrm{BoB}$ and from southern India to central BoB. The correlated variations of these trace gases and percentage residence time of air parcels over the Indian regions suggest that the enrichment of $\mathrm{O}_{3}$ and precursors in air parcels over the $\mathrm{BoB}$ is associated with both emissions and photochemistry over the Indian region. The trajectory analysis shows that the observed variation in surface $\mathrm{O}_{3}$ is primarily due to transport and en route photochemistry over the BoB during monsoon season. An analysis of modelled $\mathrm{O}_{3}$ along air mass trajectories show mean en route $\mathrm{O}_{3}$ production rate of about $4.6 \mathrm{nmol} \mathrm{mol}^{-1}$ day $^{-1}$ in the outflow towards the BoB.

The observed spatio-temporal variations of surface $\mathrm{O}_{3}$ and $\mathrm{CO}$ during summer monsoon season are generally reproduced by WRF-Chem, although the absolute mixing ratios of $\mathrm{O}_{3}$ and $\mathrm{CO}$ are typically overestimated by about 6 and 16 $\%$, respectively.

The four low- $\mathrm{O}_{3}$ events coinciding with intense rainfall were observed over the BoB. After analysing the observed variability in air temperature, model simulations of vertical winds, and an $\mathrm{O}_{3}$-profile case study from southern India, we suggest that first three low- $\mathrm{O}_{3}$ events were due to strong 
downdrafts of $\mathrm{O}_{3}$-poor air masses. Analysis of the fourth event, which is successfully reproduced by the model, shows the pivotal role of horizontal advection in transporting $\mathrm{O}_{3}$ rich air masses deeper over the BoB.

Finally, the measurements during the monsoon are combined with previous campaigns over the $\mathrm{BoB}$ during other seasons to investigate the seasonal variability in trace gases over the $\mathrm{BoB} . \mathrm{O}_{3}$ and $\mathrm{CO}$ are shown to have pronounced seasonality, $\mathrm{O}_{3}$ having amplitudes of about 39 and $27 \mathrm{nmol} \mathrm{mol}^{-1}$ and $\mathrm{CO}$ having amplitudes of about 207 and $124 \mathrm{nmol} \mathrm{mol}^{-1}$ over northern and central BoB, respectively.

Our study data fill a gap of observations during the summer monsoon over the $\mathrm{BoB}$, providing information on the extent of seasonal variability. We recommend supplementing these findings with shipborne experiments featuring collocated vertical profile observations from balloon-borne and aircraft-based platforms over the oceanic regions surrounding India to better understand the role of both large-scale dynamics (e.g. Ojha et al., 2016) and of regional influences due to South Asian outflow (see Lawrence and Lelieveld, 2010, and references therein). Such a future study would also improve our understanding of the changes that take place in the atmospheric oxidation capacity during the summer monsoon season.

\section{Data availability}

The observational data used in the paper can be obtained by contacting the corresponding author (imran.girach@gmail.com). The metadata are available on the website of Space Physics Laboratory (http://spl.gov.in/index.php?option=com_content\&view= article $\&$ id=394\&Itemid=695\&lang=en).

Acknowledgements. We thank the CTCZ and ICRP organisers for the opportunity to participate in the 2009 CTCZ experiment. We are thankful to the Director of the National Centre for Antarctic and Ocean Research (NCAOR), Goa, for providing shipboard facilities. We gratefully acknowledge G. S. Bhatt (Indian Institute of Science, Bengaluru, India) and his team for providing the measurements of meteorological parameters. We also thank the chief scientist on board Sagar Kanya for providing necessary support during the cruise. The authors gratefully acknowledge the NOAA Air Resources Laboratory (ARL) for the providing the HYSPLIT transport and dispersion model and READY website (http://www.arl.noaa.gov/ready.php) used in this publication. The rainfall estimations (3B42) from the TRMM satellite were obtained from the NASA/GSFC via their website http://mirador.gsfc.nasa.gov/. The monthly $\mathrm{CH}_{4}$ retrievals (IMAPDOAS) of SCIAMACHY were obtained from their website, http: //www.temis.nl/climate/methane.html. Use of INTEX-B and HTAP (http://edgar.jrc.ec.europa.eu/htap_v2/index.php?SECURE=123) anthropogenic emissions is gratefully acknowledged. Initial and boundary condition data for meteorological fields were used from the ERA-Interim of ECMWF. Use of MOZART-
4/GEOS5 initial and boundary condition data for chemical fields is acknowledged. Data and processors for anthropogenic emissions, biogenic emissions, and biomass burning obtained from NCAR ACD website are gratefully acknowledged. The authors acknowledge the use of MPG supercomputer HYDRA (http://www.mpcdf.mpg.de/services/computing/hydra) for model simulations. Constructive comments and suggestions from anonymous reviewers are gratefully acknowledged.

The article processing charges for this open-access publication were covered by the Max Planck Society.

Edited by: N. Harris

Reviewed by: two anonymous referees

\section{References}

Ackermann, I. J., Hass, H., Memmesheimer, M., Ebel, A., Binkowski, F. S., and Shankar, U.: Modal aerosol dynamics model for Europe: development and first applications, Atmos. Environ., 32, 2981-2999, 1998.

Ahrens, C. D.: Meteorology Today- an introduction to weather, climate, and the environment, Brooks/Cole, USA, 2009.

Ali, K., Beig G., Chate D. M., Momin, G. A., Sahu, S. K., and Safai, P. D.: Sink mechanism for significantly low level of ozone over the Arabian Sea during monsoon, J. Geophys. Res., 114, D17306, doi:10.1029/2008JD011256, 2009.

Ansari, T. U., Ojha, N., Chandrasekar, R., Balaji, C., Singh, N., and Gunthe, S. S.: Competing impact of anthropogenic emissions and meteorology on the distribution of trace gases over Indian region, J. Atmos. Chem., 73, 363-380, doi:10.1007/s10874-016-9331-y, 2016.

Anurose, T. J., Subrahamanyam D. B., and Sunilkumar S. V.: Two years observations on the diurnal evolution of coastal atmospheric boundary layer features over Thiruvananthapuram $\left(8.5^{\circ} \mathrm{N}, 76.9^{\circ} \mathrm{E}\right)$, India, Theor. Appl. Climatol., in press, doi:10.1007/s00704-016-1955-y, 2016.

Barth, M. C., Lee, J., Hodzic, A., Pfister, G., Skamarock, W. C., Worden, J., Wong, J., and Noone, D.: Thunderstorms and upper troposphere chemistry during the early stages of the 2006 North American Monsoon, Atmos. Chem. Phys., 12, 11003-11026, doi:10.5194/acp-12-11003-2012, 2012.

Bergamaschi, P., Hein, R., Heimann, M., and Crutzen, P. J.: Inverse modeling of the global $\mathrm{CO}$ cycle: 1 . Inversion of CO mixing ratios, J. Geophys. Res.-Atmos., 105, 1909-1927, doi:10.1029/1999JD900818, 2000.

Binkowski, F. S. and Shankar, U.: The regional particulate matter model: 1. Model description and preliminary results, J. Geophys. Res., 100, 26191-26209, doi:10.1029/95JD02093, 1995.

Brasseur, G. P., Orlando, J. J., and Tyndall, G. S.: Atmospheric Chemistry and Global Change. Oxford University Press, New York, 209-234, 1999.

Chen, F. and Dudhia, J.: Coupling and advanced land surfacehydrology model with the Penn State-NCAR MM5 modeling system, Part I: Model implementation and sensitivity, Mon. Weather Rev., 129, 569-585, 2001. 
Chou, M.-D. and Suarez, M. J.: An effcient thermal infrared radiation parametrization for use in general circulation models, NASA Tech. Memo., 104606, 85 pp., 1994.

Cooper, O. R., Parrish, D. D., Ziemke, J., Balashov, N. V.,Cupeiro, M., Galbally, I. E., Gilge, S., Horowitz, L. , Jensen, N. R., Lamarque, J.-F., Naik, V., Oltmans, S. J., Schwab, J., Shindell, D. T., Thompson, A. M., Thouret, V., Wang, Y., and Zbinden, R. M.: Global distribution and trends of tropospheric ozone: An observation-based review, Elementa: Science of the Anthropocene, 2, 000029, doi:10.12952/journal.elementa.000029, 2014.

Crutzen, P. J., Lawrence, M. G., and Pöschl, U.: On the background photochemistry of tropospheric ozone, Tellus, 51A, 123-146, 1999.

David, L. M. and Nair, P. R.: Diurnal and seasonal variability of surface ozone and $\mathrm{NO}_{x}$ at a tropical coastal site: Association with mesoscale and synoptic meteorological conditions, J. Geophys. Res., 116, D10303, doi:10.1029/2010JD015076, 2011.

David, L. M., Girach, I. A., and Nair, P. R.: Distribution of ozone and its precursors over Bay of Bengal during winter 2009: role of meteorology, Ann. Geophys., 29, 1613-1627, doi:10.5194/angeo-29-1613-2011, 2011.

Draxler, R. R. and Rolph, G. D.: HYSPLIT (HYbrid Single-Particle Lagrangian Integrated Trajectory) Model access via NOAA ARL READY Website (http://www.arl.noaa.gov/HYSPLIT. php), NOAA Air Resources Laboratory, Silver Spring, MD, 2003.

Finlayson-Pitts, B. J. and Pitts Jr., J. N.: Chemistry of the Upper and Lower Atmosphere: Theory, Experiments, and Applications, Academic Press, USA, 2003.

Fishman, J., Solomon, S., and Crutzen, P. J.: Observational and theoretical evidence in support of a significant in situ photochemical source of tropospheric ozone, Tellus, 31, 432-446, 1979.

Frankenberg, C., Platt, U., and Wagner, T.: Iterative maximum a posteriori (IMAP)-DOAS for retrieval of strongly absorbing trace gases: Model studies for $\mathrm{CH}_{4}$ and $\mathrm{CO}_{2}$ retrieval from near infrared spectra of SCIAMACHY onboard ENVISAT, Atmos. Chem. Phys., 5, 9-22, doi:10.5194/acp-5-9-2005, 2005.

Fung, I., John, J., Lerner, J., Matthews, E., Prather, M., Steele, L. P., and Fraser, P. J.: Three-dimensional model synthesis of the global methane cycle, J. Geophys. Res. 96, 13033-13065, 1991.

Girach, I. A. and Nair, P. R.: Spatial distribution of near-surface CO over bay of Bengal during winter: role of transport, J. Atmos. Sol. Terr. Phys., 72, 1241-1250, doi:10.1016/j.jastp.2010.07.025, 2010.

Girach, I. A. and Nair, P. R.: On the vertical distribution of carbon monoxide over Bay of Bengal during winter: role of water vapour and vertical updrafts, J. Atmos. Sol. Terr. Phys., 117, 3147, doi:10.1016/j.jastp.2014.05.003, 2014.

Girach, I. A., Nair, P. R., David, L. M., Hegde, P., Mishra, M. K., Kumar, G. M., Das, S. M., Ojha, N., and Naja, M.: The changes in near-surface ozone and precursors at two nearby tropical sites during annular solar eclipse of 15 January 2010, J. Geophys. Res., 117, D01303, doi:10.1029/2011JD016521, 2012.

Grell, G.: Prognostic evaluation of assumptions used by cumulus parameterizations, Month. Weather Rev., 121, 764-787, doi:10.1175/1520-0493(1993)121<0764:PEOAUB >2.0.CO;2, 1993.
Grell, G. A., Peckham, S. E., Schmitz, R., McKeen, S. A., Frost, G., Skamarock, W. C., and Eder, B.: Fully coupled "online" chemistrywithin the WRF model, Atmos. Environ., 39, 6957-6975, 2005.

Grell, G. A. and Devenyi, D.: A generalized approach to parameterizing convection combining ensemble and data assimilation techniques, Geophys. Res. Lett., 29, 38-1-38-4, doi:10.1029/2002GL015311, 2002.

Guenther, A., Karl, T., Harley, P., Wiedinmyer, C., Palmer, P. I., and Geron, C.: Estimates of global terrestrial isoprene emissions using MEGAN (Model of Emissions of Gases and Aerosols from Nature), Atmos. Chem. Phys., 6, 3181-3210, doi:10.5194/acp-63181-2006, 2006.

Heagle, A. S.: Ozone and crop yield, Annu. Rev. Phytopathol., 27, 397-423, 1989.

Huffman, G. J., Adler, R. F., Rudolf, B., Schneider, U., and Keehn, P. R.: Global precipitation estimates based on a technique for combining satellite-based estimates, rain gauge analysis, and NWP model precipitation information, J. Clim., 8, 1284-1295, 1995.

IPCC-AR5: Fifth Assessment Report of the Intergovernmental Panel on Climate Change, 2013.

Jacob, D.: Introduction to Atmospheric Chemistry, Princeton University Press, 1999.

Janjic, Z. I.: The surface layer in the NCEP Eta Model, Eleventh Conference on Numerical Weather Prediction, Norfolk, VA, 1923 August, Am. Meteor. Soc., Boston, Boston, MA, 354-355, 1996.

Janjic, Z. I.: Nonsingular Implementation of the Mellor-Yamada Level 2.5 Scheme in the NCEP Meso Model, NCEP office Note, 437, 61 pp., 2002.

Janssens-Maenhout, G., Crippa, M., Guizzardi, D., Dentener, F., Muntean, M., Pouliot, G., Keating, T., Zhang, Q., Kurokawa, J., Wankmüller, R., Denier van der Gon, H., Kuenen, J. J. P., Klimont, Z., Frost, G., Darras, S., Koffi, B., and Li, M.: HTAP_v2.2: a mosaic of regional and global emission grid maps for 2008 and 2010 to study hemispheric transport of air pollution, Atmos. Chem. Phys., 15, 11411-11432, doi:10.5194/acp15-11411-2015, 2015.

Kavitha, M. and Nair P. R.: Region-dependent seasonal pattern of methane over Indian region asobserved by SCIAMACHY, Atmos. Environ., 131, 316-325, doi:10.1016/j.atmosenv.2016.02.008, 2016.

Komhyr, W. D.: Electrochemical concentration cells for gas analysis, Ann. Geophys., 25, 203-210,1969.

Komhyr, W. D., Barnes, R. A., Brothers, G. B., Lathrop, J. A., and Opperman, D. P.: Electrochemical concentration cell ozonesonde performance evaluation during STOIC 1989, J. Geophys. Res., 100, 9231-9244, doi:10.1029/94JD02175, 1995.

Kishore Kumar, K., Jain, A. R., and Narayana Rao, D.: VHF/UHF radar observations of tropical mesoscale convective systems over southern India, Ann. Geophys., 23, 1673-1683, doi:10.5194/angeo-23-1673-2005, 2005.

Kumar, R., Naja, M., Pfister, G. G., Barth, M. C., and Brasseur, G. P.: Simulations over South Asia using the Weather Research and Forecasting model with Chemistry (WRF-Chem): set-up and meteorological evaluation, Geosci. Model Dev., 5, 321-343, doi:10.5194/gmd-5-321-2012, 2012a. 
Kumar, R., Barth, M. C., Nair, V. S., Pfister, G. G., Suresh Babu, S., Satheesh, S. K., Krishna Moorthy, K., Carmichael, G. R., Lu, Z., and Streets, D. G.: Sources of black carbon aerosols in South Asia and surrounding regions during the Integrated Campaign for Aerosols, Gases and Radiation Budget (ICARB), Atmos. Chem. Phys., 15, 5415-5428, doi:10.5194/acp-15-5415-2015, 2015 b.

Kumar, R., Naja, M., Pfister, G. G., Barth, M. C., Wiedinmyer, C., and Brasseur, G. P.: Simulations over South Asia using the Weather Research and Forecasting model with Chemistry (WRFChem): chemistry evaluation and initial results, Geosci. Model Dev., 5, 619-648, doi:10.5194/gmd-5-619-2012, 2012 b.

Kumar, R., M. C. Barth, G. G. Pfister, V. S. Nair, S. D. Ghude, and Ojha N.: What controls the seasonal cycle of black carbon aerosols in India?, J. Geophys. Res.-Atmos., 120, 7788-7812, doi:10.1002/2015JD023298, 2015a.

Lal, S., Chand, D., Sahu, L. K., Venkataramani, S., Brasseur, G., and Schultz, M. G.: High levels of ozone and related gases over the Bay of Bengal during winter and early spring of 2001, Atmos. Environ., 40, 1633-1644, 2006.

Lal, S. and Lawrence, M. G.: Elevated mixing ratios of surface ozone over the Arabian Sea, Geophys. Res. Lett., 28, 1487-1490, 2001.

Lal, S., Naja, M., and Subbaraya, B. H.: Seasonal variations in surface ozone and its precursors over an urban site in India, Atmos. Environ., 34, 2713-2724, doi:10.1016/S1352-2310(99)00510-5, 2000.

Lal, S., Sahu, L. K., and Venkataramani, S.: Impact of transport from the surrounding continental regions on the distributions of ozone and related trace gases over the Bay of Bengal during February 2003, J. Geophys. Res., 112, D14302, doi:10.1029/2006JD008023, 2007.

Lawrence, M. G. and Lelieveld, J.: Atmospheric pollutant outflow from southern Asia: a review, Atmos. Chem. Phys., 10, 1101711096, doi:10.5194/acp-10-11017-2010, 2010.

Lelieveld, J. and Dentener, F. J.: What controls tropospheric ozone?, J. Geophys. Res., 105, 3531-3551, doi:10.1029/1999JD901011, 2000.

Lelieveld, J., Crutzen, P. J., Ramanathan, V., Andreae, M. O., Brenninkmeijer, C. A. M., Campos, T., Cass, G. R., Dickerson, R. R., Fischer, H., de Gouw, J. A., Hansel, A., Jefferson, A., Kley, D., de Laat, A. T. J., Lal, S., Lawrence, M. G., Lobert, J. M., MayolBracero, O. L., Mitra, A. P., Novakov, T., Oltmans, S. J., Prather, K. A., Reiner, T., Rodhe, H., Scheeren, H. A., Sikka, D., and Williams, J.: The Indian Ocean experiment: Widespread air pollution from South and Southeast Asia, Science, 291, 1031-1036, 2001.

Lelieveld, J., Berresheim, H., Borrmann, S., Crutzen, P. J., Dentener, F. J., Fischer, H., Feichter, J., Flatau, P. J., Heland, J., Holzinger, R., Korrmann, R., Lawrence, M. G., Levin, Z., Markowicz, K. M., Mihalopoulos, N., Minikin, A., Ramanathan, V., de Reus, M., Roelofs, G. J., Scheeren, H. A., Sciare, J., Schlager, H., Schultz, M., Siegmund, P., Steil, B., Stephanou, E. G., Stier, P., Traub, M., Warneke, C., Williams, J., and Ziereis, H.: Global Air Pollution Crossroads over the Mediterranean, Science, 298, 794-799, doi:10.1126/science.1075457, 2002.

Lin, Y.-L., Farley, R. D., and Orville, H. D.: Bulk Parameterization of the Snow Field in a Cloud Model, J. Clim. Appl. Meteorol., 22, 1065-1092, 1983.
Mahapatra, P. S., Panda, S., Walvekar, P. P., Kumar, R., Das, T., and Gurjar, B. R.: Seasonal trends, meteorological impacts, and associated health risks with atmospheric concentrations of gaseous pollutants at an Indian coastal city, Environ. Sci. Pollut. Res., 21, 11418-11432, doi:10.1007/s11356-014-3078-2, 2014.

Mallik, C., Lal, S., Venkataramani, S., Naja, M., and Ojha, N.: Variability in ozone and its precursors over the Bay of Bengal during post monsoon: Transport and emission effects, J. Geophys. Res.Atmos., 118, 10190-10209, doi:10.1002/jgrd.50764, 2013.

Mlawer, E. J., Taubman, S. J., Brown, P. D., Iacono, M. J., and Clough, S. A.: Radiative transfer for inhomogeneous atmospheres: RRTM, a validated correlated-k model for the longwave, J. Geophys. Res.-Atmos., 102, 16663-16682, doi:10.1029/97JD00237, 1997.

Mühle, J., Zahn, A., Brenninkmeijer, C. A. M., Gros, V., and Crutzen, P. J.: Air mass classification during the INDOEX R/V cruise using measurements of non-methane hydrocarbons, $\mathrm{CH}$, $\mathrm{CO}_{2}, \mathrm{CO},{ }^{14} \mathrm{CO}$, and $\delta 18 \mathrm{O}(\mathrm{CO})$, J. Geophys. Res., 107, 8021, doi:10.1029/2001JD000730, 2002.

Monks, P. S., Archibald, A. T., Colette, A., Cooper, O., Coyle, M., Derwent, R., Fowler, D., Granier, C., Law, K. S., Mills, G. E., Stevenson, D. S., Tarasova, O., Thouret, V., von Schneidemesser, E., Sommariva, R., Wild, O., and Williams, M. L.: Tropospheric ozone and its precursors from the urban to the global scale from air quality to short-lived climate forcer, Atmos. Chem. Phys., 15, 8889-8973, doi:10.5194/acp-15-8889-2015, 2015.

Moorthy, K. K., Nair, V. S., Babu S. S., and Satheesh S. K.: Spatial and vertical heterogeneities of aerosol radiative forcing over the oceanic regions surrounding the Indian peninsula: climate implications, Q. J. Roy Meteorol. Soc., 135, 2131-2145, 2009.

Nair, P. R., Chand, D., Lal, S., Modh, K. S., Naja, M., Parameswaran, K., Ravindran, S., and Venkataramani, S.: Temporal variations in surface ozone at Thumba $\left(8.6^{\circ} \mathrm{N}, 77^{\circ} \mathrm{E}\right)-$ a tropical coastal site in India, Atmos. Environ., 36, 603-610, doi:10.1016/S1352-2310(01)00527-1, 2002.

Nair, P. R., David, L. M., Girach, I. A., and George, S. K.: Ozone in the marine boundary layer of Bay of Bengal during post-winter period: Spatial pattern and role of meteorology, Atmos. Environ., 45, 4671-4681, 2011.

Nair, V. S., Satheesh, S. K., Moorthy, K. K., Babu, S. S., George, S. K., and Nair, P. R.: Surprising observation of large Anthropogenic Aerosol Fraction over the near-pristine Southern Bay of Bengal: Climate Implications, J. Geophys. Res.-Atmos., 115, D21201, doi:10.1029/2010JD013954, 2010.

Naja, M., Lal, S., and Chand, D.: Diurnal and seasonal variabilities in surface ozone at a high altitude site $\mathrm{Mt}$ Abu $\left(24.6^{\circ} \mathrm{N}\right.$, $72.7^{\circ} \mathrm{E}, 1680 \mathrm{~m}$ a.s.1.) in India, Atmos. Environ., 37, 4205-4215, doi:10.1016/S1352-2310(03)00565-X, 2003.

Naja, M., Chand, D., Sahu, L., and Lal, S.: Trace gases over marineregions around India, Ind. J. Mar. Sci., 33, 95-106, 2004.

Nishanth, T., Praseed, K. M., Satheesh Kumar, M. K., and Valsaraj, K. T.: Observational Study of Surface $\mathrm{O}_{3}, \mathrm{NO}_{x}, \mathrm{CH}_{4}$ and Total NMHCs at Kannur, India, Aerosol Air Qual. Res., 14, 10741088, doi:10.4209/aaqr.2012.11.0323, 2014.

Ojha, N., Naja, M., Singh, K. P., Sarangi, T., Kumar, R., Lal, S., Lawrence, M. G., Butler, T. M., and Chandola, H. C.: Variabilities in ozone at a semi-urban site in the Indo-Gangetic Plain region: Association with the meteorology and regional process, J. Geophys. Res., 117, D20301, doi:10.1029/2012JD017716, 2012. 
Ojha N., Naja, M., Sarangi, T., Kumar, R., Bhardwaj, P., Lal, S., Venkataramani, S., Sagar, R., Kumar, A., Chandol, H. C.: On the processes influencing the vertical distribution of ozone over the central Himalayas: Analysis of yearlong ozonesonde observations, Atmos. Environ., 88, 201-211, doi:10.1016/j.atmosenv.2014.01.031, 2014.

Ojha, N., Pozzer, A., Rauthe-Schöch, A., Baker, A. K., Yoon, J., Brenninkmeijer, C. A. M., and Lelieveld, J.: Ozone and carbon monoxide over India during the summer monsoon: regional emissions and transport, Atmos. Chem. Phys., 16, 3013-3032, doi:10.5194/acp-16-3013-2016, 2016.

Randel, W. J., Park, M., Emmons, L., Kinnison, D., Bernath, P., Walker, K. A., Boone, C., and Pumphrey, H.: Asian monsoontransport of pollution to the stratosphere, Science, 328, 611-613, 2010.

Ravikumar, K., Tiwari, Y. K., Valsala, V., and Murtugudde, R.: On understanding of land-ocean $\mathrm{CO}_{2}$ contrast over Bay of Bengal: A case study during 2009 summer monsoon, Environ. Sci. Pollut. Res., 21-27, 5066-5075, doi:10.1007/s11356-013-2386-2, 2014.

Reddy, B. S. K., Reddy, L. S. S., Cao J., Kumar, K. R., Balakrishnaiah, G., Gopal, K. R, Reddy, R. R., Narasimhulu K., Lal, S., and Ahammed, Y. N.: Simultaneous Measurements of Surface Ozone at Two Sites over the Southern Asia: A Comparative Study, Aerosol Air Qual. Res., 11, 895-902, doi:10.4209/aaqr.2011.05.0061, 2011.

Rolph, G. D.: Real-time Environmental Applications and Display sYstem (READY) Website (http://www.arl.noaa.gov/ready.php), NOAA Air Resources Laboratory, Silver Spring, MD, 2003.

Sahu, L.K., Lal, S., and Venkataramani, S.: Distributions of $\mathrm{O}_{3}, \mathrm{CO}$ and hydrocarbons over the Bay of Bengal: a study to assess the role of transport from southern India and marine regions during Septembere October 2002, Atmos. Environ., 40, 4633-4645, 2006

Sawa, Y., Tanimoto, H., Yonemura, S., Matsueda, H., Wada, A., Taguchi, S, Hayasaka, T., Tsuruta, H., Tohjima, Y., Mukai, H., Kikuchi, N., Katagiri, S., and Tsuboi, K.: Widespread pollution events of carbon monoxide observed over the western North Pacific during the East Asian Regional Experiment (EAREX) 2005 campaign, J. Geophys. Res., 112, D22S26, doi:10.1029/2006JD008055, 2007.

Scheeren, H. A., Lelieveld, J., Roelofs, G. J., Williams, J., Fischer, H., de Reus, M., de Gouw, J. A., Warneke, C., Holzinger, R., Schlager, H., Klüpfel, T., Bolder, M., van der Veen, C., and Lawrence, M.: The impact of monsoon outflow from India and Southeast Asia in the upper troposphere over the eastern Mediterranean, Atmos. Chem. Phys., 3, 1589-1608, doi:10.5194/acp-31589-2003, 2003.

Schell, B., Ackermann, I. J., Hass, H., Binkowski, F. S., and Ebel, A.: Modeling the formation of secondary organic aerosol within a comprehensive air quality model system, J. Geophys. Res., 106, 28275-28293, 2001.

Seinfeld, J. H. and Pandis, S. N.: Atmospheric Chemistry and Physics: from air pollution to climate change, 2nd Edn., WileyInterscience publication, USA, 2006.

Smit, H. G. J., Straeter, W., Johnson, B. J., Oltmans, S., Davies, J., Tarasick, D. W., Hoegger, B., Stubi, R., Schmidlin, F., Northam, T., Thompson, A. M., Witte, J. C., Boyd, I., and Posny, F.: Assessment of the performance of ECC-ozonesondes under quasi-flight conditions in the environmental simulation chamber: insights from the Juelich Ozone SondeIntercomparison Experiment (JOSIE), J. Geophys. Res. 112, D19306, doi:10.1029/2006JD007308, 2007.

Sprenger, M., Wernli, H., and Bourqui, M.: StratosphereTroposphere exchange and its relation to potential vorticity streamers and cutoffs near the extratropical tropopause, J. Atmos. Sci., 64, 1587-1604, 2007.

Srivastava, S., Lal, S., Venkataramani, S., Gupta, S., and Acharya, Y. B.: Vertical distribution of ozone in the lower troposphere over the Bay of Bengal and the Arabian Sea during ICARB-2006: Effects of continental outflow, J. Geophys. Res., 116, D13301, doi:10.1029/2010JD015298, 2011.

Srivastava, S., Lal, S., Venkataramani, S., Gupta, S., and Sheel, V.: Surface distributions of $\mathrm{O}_{3}, \mathrm{CO}$ and hydrocarbons over the Bay of Bengal and the Arabian Sea during pre-monsoon season, Atmos. Environ., 47, 459-467, doi:10.1016/j.atmosenv.2011.10.023, 2012.

Stockwell, W. R., Middleton, P., Chang, J. S., and Tang, X.: The second generation regional acid deposition model chemical mechanism for regional air quality modeling, J. Geophys. Res., 95, 16343-16367, doi:10.1029/JD095iD10p16343, 1990.

Subrahamanyam, D. B., Anurose, T. J., Kiran Kumar, N. V. P., Mohan, M., Kunhikrishnan, P. K., John, S. R., Prijith, S. S., and Dutt, C. B. S.: Spatial and temporal variabilities in vertical structure of the Marine Atmospheric Boundary Layer over Bay of Bengal during Winter Phase of Integrated Campaign for Aerosols, gases and Radiation Budget, Atmos. Res., 107, 178185, doi:10.1016/j.atmosres.2011.12.014, 2012.

Tanimoto, H., Mukai, H., Sawa, Y., Matsueda, H., Yonemura, S.,Wang, T., Poon, S., Wong, A., Lee, G., Jung, J. Y., Kim, K. R., Lee, M. H., Lin, N. H., Wang, J. L., Ou-Yang, C. F., Wu, C. F., Akimoto, H., Pochanart, P., Tsuboi, K., Doi, H., Zellweger, C., and Klausen, J.: Direct assessment of international consistency of standards for ground-level ozone: Strategy and implementation toward metrological traceability network in Asia, J. Environ. Monit., 9, 1183-1193, doi:10.1039/b701230f, 2007.

Tiwari, Y. K. and RaviKumar, K.: Glass flask air sample analysis through gas chromatography in India: implications for constraining $\mathrm{CO}_{2}$ surface fluxes, WMO/GAW Report No. 194, WMO/TDNo. 1553, April 2011, 2011.

World Health Organization: Environmental Health Criteria 213, Carbon monoxide, 1999.

Wiedinmyer, C., Akagi, S. K., Yokelson, R. J., Emmons, L. K., AlSaadi, J. A., Orlando, J. J., and Soja, A. J.: The Fire INventory from NCAR (FINN): a high resolution global model to estimate the emissions from open burning, Geosci. Model Dev., 4, 625641, doi:10.5194/gmd-4-625-2011, 2011.

Zhang, Q., Streets, D. G., Carmichael, G. R., He, K. B., Huo, H., Kannari, A., Klimont, Z., Park, I. S., Reddy, S., Fu, J. S., Chen, D., Duan, L., Lei, Y., Wang, L. T., and Yao, Z. L.: Asian emissions in 2006 for the NASA INTEX-B mission, Atmos. Chem. Phys., 9, 5131-5153, doi:10.5194/acp-9-5131-2009, 2009. 